\title{
Les intermédiaires techniques et l'agentivité des objets
}

Comment les ingénieurs du son contribuent au sens des concerts

Technical Intermediaries and the Agency of Objects. How Sound Engineers Make Meaning in Live Music Production

Los intermediarios técnicos y la agencividad de los objetos. Cómo los ingenieros

del sonido producen sentido en la producción de música en conciertos

\section{Andy Battentier et Giselinde Kuipers}

Traducteur : Dario Rudy

\section{(2) OpenEdition}

\section{Journals}

Édition électronique

URL : http://journals.openedition.org/bssg/442

DOI : $10.4000 /$ bssg.442

ISSN : 2490-9424

Éditeur

Presses universitaires de Vincennes

Référence électronique

Andy Battentier et Giselinde Kuipers, "Les intermédiaires techniques et l'agentivité des objets », Biens Symboliques / Symbolic Goods [En ligne], 6 | 2020, mis en ligne le 30 avril 2020, consulté le 04 mars 2021. URL : http://journals.openedition.org/bssg/442 ; DOI : https://doi.org/10.4000/bssg.442 
Les intermédiaires techniques et l'agentivité des objets

\author{
Comment les ingénieurs du son
} contribuent au sens des concerts

\section{Technical Intermediaries and the Agency of Objects}

\author{
How Sound Engineers Make Meaning \\ in Live Music Production
}

\author{
Andy Battentier | Giselinde Kuipers \\ traduction | translation \\ Dario Rudy
}

1. Introduction : produire de la musique et du sens dans des configurations matérielle

Récemment, le média en ligne The Verge s'est demandé comment il était possible que le spectacle de la mi-temps du Super Bowl, un événement musical placé à la mi-temps de la finale du championnat de football américain et suivi par plus de cent millions de téléspectateurs du monde entier, puisse être entièrement installé en à peine six minutes. L'article cite Patrick Baltzell, qui est le « responsable du son des dix-neuf derniers Super Bowl », et qui « conçoit et mixe pour les Grammy Awards, les Oscars, et les investitures présidentielles ». Dans cette interview, le journaliste montre au grand jour la prouesse cachée que constitue cette interprétation sonore en direct. Le travail de Baltzell, qui consiste à la fois à superviser le travail de fourmi de construction de la scène et à mixer le son de la performance sur place, nécessite de faire coïncider les contraintes matérielles, les exigences du producteur et celles des interprètes musicaux. L'interview évoque une myriade d'éléments impliqués dans la création de la performance finale :

\section{Introduction: Producing Music and Meaning in} Material Settings

Recently, the online medium The Verge tried to find out how the Super Bowl halftime show, a musical event during the final of the US football championship with more than one hundred million spectators from around the world, was set up in just six minutes. The article cites Patrick Baltzell who was "in charge of the audio for the last nineteen Super Bowls" and also "designs and mixes for the Grammys, Oscars, and presidential inaugurations." In this interview, the journalist brought to the fore the hidden artistry of this live sound performance. Baltzell's work, which consists both of managing the minute preparations for the ant ballet building the stage, and of mixing the performance's sound on the spot, requires a careful coordination of material constraints and the demands of the producer and performers. The interview mentions a plethora of elements involved in creating the final performance: the weather and the stadium acoustics, the requests of the artistic performers, 
la météo, l'acoustique du stade, les demandes des artistes, les conditions nécessaires pour la diffusion. Tous ces éléments sont cités comme des paramètres à prendre en compte pour produire la

meilleure prestation possible.

Cette coordination constante entre des contraintes matérielles et des exigences interpersonnelles est typique de la dimension technique de la production culturelle, comme c'est le cas dans les productions sonores et visuelles, telle que celle du Super Bowl. Dans la sociologie de la culture et des arts, des travaux récents ont souligné " l'agentivité des objets ", c'est-à-dire leur capacité à influer sur les situations sociales. Inspirées par les études des sciences et technologies et la théorie de l'acteur-réseau, les approches dites néomatérialistes en sociologie de la culture ont placé les objets et l'environnement matériel au cœur de leur analyse de la production culturelle. Ces travaux ont souligné les " affordances » (ou potentialités) offertes par les artefacts et les objets musicaux et la possibilité qu'ont les gens de " s'attacher " aux choses (DeNora 2000 ; Gomart \& Hennion 1999 ; Hennion 2007). D'autres ont mis en évidence la capacité des objets et des environnements à modeler le processus de prise de décision dans la production culturelle (Akrich 1992, 1993, 2010 ; Domínguez Rubio 2012, 2014 ; Griswold, Mangione, McDonnell 2013 ; Klett 2014). En retour, ces approches ont récemment été critiquées pour avoir surestimé l'influence des technologies, des objets et des environnements dans la fabrique de la vie sociale, minimisant le rôle des processus sociaux, des relations de pouvoir et des développements historiques (Elder-Vass 2008, 2015 ; Lettow

2017).

Dans cet article, nous souhaitons poursuivre cette critique à l'égard de « l'agentivité des objets ». Nous interrogeons la « symétrie généralisée »(Callon 1986), centrale dans la théorie de l'acteur- the broadcasting requirements-all are cited as elements taken into consideration in order to produce the best possible performance.

This constant coordination between material constraints and interpersonal demands is typical of the technical aspect of cultural production, as it happens in sound and visual production such as the Super Bowl. Recent approaches in the sociology of culture and the arts highlighted "the agency of objects": the capacity of objects to influence social situations. Inspired by science and technology studies (STS) and Actor-Network Theory (ANT), so-called new materialist approaches in cultural sociology have placed objects and the material environment at the center of the analysis of cultural production. Thus, they have stressed "affordances" offered by musical artifacts and objects, and the possibility for people to "attach" themselves to things (DeNora 2000; Gomart \& Hennion 1999; Hennion 2007). Others have stressed the ability of objects and environments to shape decision-making in cultural production (Akrich 1992, 1993, 2010; Domínguez Rubio 2012, 2014; Griswold, Mangione, McDonnell 2013; Klett 2014). These approaches, in turn, have recently been criticized for overstating the influence of technologies, objects and environments in shaping social life, and thus downplaying the role of social processes, power relations and historical developments (Elder-Vass 2008, 2015; Lettow 2017).

In this paper, we aim to follow up on this critique on the "agency of objects." We question the "generalized symmetry" (Callon 1984), central to ANT, that places human and non-human actors 
réseau, qui attribue aux acteurs humains et non humains un même niveau d'influence. Nous en appelons à une approche de la matérialité qui s'intéresse au rôle des objets tout en prenant en compte le fait qu'ils exercent une influence de nature/d'un type différente. Pour ce faire, nous allons démontrer que si aujourd'hui la production d'un bien symbolique nécessite parfois un investissement important en technologies et en objets, les relations humaines et les processus de production du sens demeurent le facteur central pour en déterminer la forme finale.

Pour cela, nous nous intéresserons à un groupe spécifique de producteurs culturels qui est fortement concerné par la manipulation d'objets et de matériaux. Ils sont généralement désignés sous le nom « d'équipe technique » et nous introduirons le terme « d'intermédiaires techniques » au sein des mondes de l'art pour parler de cette catégorie spécifique de travailleurs. Les personnes désignées par ce vocable sont les ingénieurs et les techniciens qui sont aux prises avec la matérialité lors de la production d'objets ou d'événements culturels. Nous décrivons ces personnes comme des intermédiaires car leur action est constituée de médiations variées. Cette médiation est « technique », car elle lie des personnes et des objets. En outre, dans l'exercice de cette médiation, les intermédiaires techniques s'appuient sur la technologie : des outils ou des dispositifs manipulés par les humains afin de travailler sur des objets physiques.

Cet article analyse le travail d'un groupe spécifique d'intermédiaires techniques : les ingénieurs du son des concerts de musique live. II clarifie la façon dont leurs tâches, leurs décisions et leurs pratiques résultent à la fois des paramètres interindividuels et matériels des situations sociales. Nous montrerons que le travail des techniciens son est composé de différentes formes de médiation. Ils servent tout d'abord de médiateurs entre les biens symboliques (la musique) et on a same level of influence. Instead, we call for an approach to materiality that accounts for the role of objects, while considering their influence as different in kind. In order to do this, we will show that while the contemporary production of a symbolic good sometimes engages a massive investment of technologies and objects, human relationships and processes of meaning-making stay the central factor influencing its final shape.

For this, we will focus on the specific group of cultural producers that is strongly concerned with manipulating objects and materials. Commonly referred to as the "tech crew," we introduce the term "technical intermediaries" within art worlds to designate this specific category of workers. People designated under this label are the engineers and technicians who practically engage with materiality during the production of cultural objects or events. We refer to this category as intermediaries because their work consists of mediation, in various ways. However, this mediation is "technical" as it mediates between people and material objects. Moreover, in doing this mediation, such technical intermediaries rely on technologies: tools or devices manipulated by humans in order to work on physical objects.

This article analyzes the work of a specific group of technical intermediaries: sound technicians of live music concerts. It untangles how their tasks, decision and practices result from both interindividual and material elements of the social situations. We will show that sound technicians' work consists of various forms of mediation. First, they mediate between symbolic goods (music) and physical matter (sound waves). Second, they mediate between 
la matière physique (les ondes sonores). Ensuite, ils servent de médiateurs entre différentes catégories de producteurs culturels : les musiciens, mais aussi les techniciens, et autres personnels de renfort. Ainsi, ils effectuent une médiation « matérielle » aussi bien que " relationnelle ». Troisièmement, ils servent évidemment de médiateurs entre les musiciens et leur public. Et, ce de manière littérale : la plus grande part de la musique interprétée de nos jours en Europe occidentale nécessite pour son exécution le travail d'un technicien, et sans leur contribution, celle-ci ne pourrait pas être appréciée, voire comprise comme de la musique.

L'objectif de cet article est double. Tout d'abord nous introduirons la notion d'intermédiaires techniques comme une catégorie d'acteurs des mondes de l'art (Becker 2010). Nous proposons de diviser les travailleurs des mondes de l'art en quatre catégories principales : les artistes, le public, les intermédiaires culturels et les intermédiaires techniques. Nous nous intéressons aux modalités et à l'étendue de la contribution des intermédiaires techniques à la production de biens symboliques, en nous penchant sur le cas empirique des techniciens son de musique live. Plus spécifiquement, nous enquêtons sur les modalités et l'ampleur de leur médiation supposément « neutre », « technique » ou « d'assistance », et la façon dont celle-ci permet de produire du sens et de la valeur.

Deuxièmement, nous analyserons la façon dont le sens et la valeur sont produits par le biais de la médiation technique et matérielle exercée spécifiquement par les intermédiaires techniques, en démêlant les aspects relationnels et matériels de leur travail. Nous défendrons le primat des processus interindividuels, généralement qualifiés de "sociaux ». Par conséquent, nous considérerons " l'agentivité des objets » comme le résultat d'une « aptitude technique »: la capacité des groupes, des individus et des institutions, provoquée par la socialisation, à répondre à des défis different categories of cultural producers: musicians, but also the technicians and other support personnel. Thus, they perform both "material" mediation, as well as "relational mediation." Third, obviously, they mediate between musicians and their audiences. The do so quite literally: most music performed live today in Western Europe is intended to be worked upon by technicians, and without their contribution would not be appreciated, or not even be understood as music.

The aim of this paper is twofold. First, we introduce the notion of technical intermediaries as a category of actors in art worlds (Becker 1982). We propose to collapse art world workers into four main categories: artists, audiences, cultural intermediaries and technical intermediaries. We explore how and to what extent technical intermediaries contribute to the production of symbolic goods, through the empirical case of sound technicians of live music. More specifically, we investigate how, and to what extent, their supposedly "neutral" "technical" or "support" mediation work creates meaning and adds value.

Second, we analyze how meaning and value are created via the technical and material mediation specifically performed by technical intermediaries, untangling relational and material aspects of their work. We argue for the primacy of the influence of interindividual processes, classically considered as "social" in the literature. Consequently, we understand the "agency of objects" as a result of "technical ability": the capacity of groups, individuals and institutions, induced by socialization, to overcome challenges posed by objects and environments and to wield them to their needs. 
posés par des objets et des environnements et à les adapter à leurs besoins.

\section{L'agentivité matérielle dans les mondes de l'art est du ressort des intermédiaires techniques}

Pour atteindre les objectifs de cet article, nous rassemblons des idées issues de trois corpus de littérature. Premièrement, nous combinerons des notions de sociologie de la culture sur les intermédiaires culturels avec le concept de Becker de « mondes de l'art » pour formuler la notion d'intermédiaires techniques. Deuxièmement, nous utiliserons sur les débats récents sur le rôle du monde matériel dans la vie sociale, et en particulier le débat portant sur l'agentivité des objets. Troisièmement, nous emprunterons des éléments d'analyse empirique à la sociologie des organisations pour comprendre les variations dans les pratiques professionnelles des intermédiaires techniques.

\subsection{Les intermédiaires techniques dans les mondes de l'art}

Qu'est-ce qui distingue l'équipe de personnes qui, au sein de la division du travail de la production culturelle, prend en charge la relation à la matière ? Dans Les Mondes de l'art (Becker 2010), Howard Becker identifie huit catégories d'acteurs nécessaires à la production d'une œuvre d'art : artistes, fournisseurs, financiers, distributeurs, public, critiques, législateurs, et personnel de renfort. Les techniciens sont inclus dans la catégorie de « personnel de renfort » qui est définie de façon assez vague comme « une catégorie diverse conçue pour contenir tout ce qui ne trouve pas facilement sa place au sein des autres catégories » (Becker 2010). Comme le remarque Howard Becker, la convention consistant à séparer l'activité artistique en une activité cardinale, réalisée par l'artiste, et des tâches moins pertinentes et nécessitant moins de talent, exécutées par le personnel de renfort, vient davantage des

\section{Material Agency in Art Worlds as the Work of Technical Intermediaries}

In order to achieve the aims of this paper, we bring together insights from three bodies of literature. First, we combine insights from cultural sociology about cultural mediation and cultural intermediaries with Howard Becker's notion of art worlds to coin the notion of technical intermediaries. Second, we draw on recent discussions on the role of materiality in social life and in particular the discussion whether objects have agency. We finally borrow a frame of empirical analysis from sociology of organizations to understand variations in the working practices of technical intermediaries.

\subsection{Technical Intermediaries in Art Worlds}

What distinguishes the crew of people that, in the division of labor of a cultural production, engage with materiality? In Art Worlds (Becker 1982), Howard Becker identifies eight categories of actors necessary for the production of an artwork: artists, suppliers, funders, distributors, audience, critics, legislators and support personnel. The tech crew is included in the category of "support personnel," which is loosely described as "a miscellaneous category designed to hold whatever the other categories do not make an easy place for" (Becker 1982: 2). As Howard Becker notes, the convention to divide artistic production into a core activity, performed by artists, and support personnel doing the less relevant and talent-requiring tasks, is endogenous to art worlds rather than driven by sociological analysis (Becker 1982: 77). Indeed, the criteria to separate an "artist" from "support personnel" are unclear: "every function in an 
mondes de l'art eux-mêmes que de l'analyse sociologique (Becker 2010). En effet, les critères permettant de distinguer les " artistes » du « personnel de renfort » sont plutôt flous : « dans un monde de l'art, toute fonction peut être tenue pour artistique et tout ce que fait un artiste, même le plus incontesté, peut devenir une activité de renfort pour quelqu'un d'autre » (Becker 2010). Du point de vue d'un chef d'orchestre ou d'un compositeur, le musicien interprétant la partition pour violon d'une symphonie peut être considéré comme « du renfort » (Becker 2010)

Ainsi, le personnel de renfort ne définit pas exactement une catégorie stable d'acteurs dotés d'un rôle spécifique. II décrit davantage un système de délégation où les tâches considérées comme « non artistiques » sont déléguées à un groupe varié de personnes. Ce système pouvant revêtir de nombreuses formes différentes, et n'étant pas limité dans le temps, il ne nous semble pas propice à décrire le travail des techniciens.

Ces dernières années, la notion de «médiation » a permis aux chercheurs de s'intéresser aux personnes qui, au sein des mondes de l'art, dressaient des ponts entre les artistes et leur public, en les regroupant sous le terme d'intermédiaires culturels (Lizé 2016 ; Maguire \& Matthews 2012 ; Negus 2002). Ce terme désigne un groupe dont le rôle s'est progressivement affirmé ces dernières décennies : les agents, les tourneurs, les chargés de communication. Au sein de la production culturelle, ces intermédiaires « construisent de la valeur en encadrant la façon dont d'autres personnes (les consommateurs finaux, mais aussi d'autres acteurs du marché, parmi lesquels se trouvent d'autres intermédiaires culturels) vont réagir lorsqu'ils sont confrontés à certains biens, en essayant d'affecter l'opinion des personnes face à ces biens et de les leur présenter comme légitimes, les "biens" pouvant inclure des produits matériels, mais aussi des services, art world can be taken seriously as art, and everything that even the most accepted artist does can become support work for someone else" (Becker 1982: 91). From the perspective of a director or a composer, the interpreter of the violin part of a symphony may be considered "supporting" (Becker 1982: 80-83).

Hence, support personnel does not properly describe a bounded category of actors with a specific role. Instead, it describes a system of delegation of tasks, where tasks considered "not artistic" are delegated to a range of people. If this system can take many different forms, and is not fixed in time, we conclude that it cannot be used as a category describing the work of tech crews.

In recent years, the notion of "mediation" has allowed researchers to focus on people that bridge relations between artists and audiences within art worlds, in particular through the label of cultural intermediaries (Lizé 2016; Maguire \& Matthews 2012; Negus 2002). This term refers to a group of people that in recent decades has become much more salient in cultural production: the agents, bookers, public relations persons, buyers and sellers of cultural products. In cultural production, such cultural intermediaries "construct value, by framing how others-end consumers, as well as other market actors including other cultural intermediariesengage with goods, affecting and effecting others' orientations towards those goods as legitimate-with 'goods' understood to include material products as well as services, ideas and behaviors" (Maguire \& Matthews 2012: 552). Cultural intermediaries "impact upon notions of what, and thereby who is legitimate, desirable and 
des idées ou des comportements " (Maguire \& Matthews 2012 : 552). Les intermédiaires culturels « interviennent sur la perception de ce qui (et donc de qui) est légitime, désirable et digne d'intérêt et par conséquent de ce qui (et de qui) ne l'est pas » (Maguire \& Matthews $2012: 552$ )

Bien que les techniciens transforment des idées artistiques en objets spécifiques, modifiant directement la façon dont les spectateurs, auditeurs, lecteurs, etc., entreront en contact avec un bien culturel, ils rentrent difficilement dans le cadre de la définition générale des activités des intermédiaires culturels. Cela devient particulièrement évident lorsqu'on analyse la typologie des intermédiaires culturels de Wenceslas Lizé (2016). Tous ces intermédiaires s'intéressent avant tout à l'accès au marché d'œuvres et d'artistes, en portant ces biens symboliques à l'attention du public général, en tant que directeurs d'institution, médiateurs ou distributeurs. Ils offrent un cadre à la réception du public en partageant leur opinion en tant que critiques. Ils modèlent et produisent du capital symbolique. Ils peuvent aller jusqu'à produire des rencontres pour déclencher la production de projets artistiques féconds (Lingo \& O'Mahony 2010). En revanche, ils ne modifient pas directement l'aspect matériel des œuvres, ce travail étant pris en charge par le « personnel de renfort », ou les techniciens : cameramen, monteurs, machinistes ou ingénieurs du son.

Ce groupe est de facto exclu de cette notion de « médiation culturelle ", leur rôle ne leur donnant pas le pouvoir de faire accéder les œuvres au marché. Cette différence a été remarquée par David Hesmondhalgh (2006), qui a plaidé pour une grille d'interprétation plus inclusive et proposé le terme d'« équipe de projet ». David Wright (2005) a essayé de rendre compte de cette séparation en distinguant les «producteurs de sens " des «producteurs d'objets ». Si les intermédiaires culturels se rangent worthy, and thus by definition what and who is not" (Maguire \& Matthews 2012: 552).

Although technical crews materialize artistic ideas into specific objects, and thus directly impact the way viewers, listeners, readers etc. will engage with cultural goods, they hardly fit the general understanding of what cultural intermediaries do. This becomes evident when considering Wenceslas Lizé's typology (2016) of cultural intermediaries. All these intermediaries focus on market access of artworks and artists, by bringing symbolic goods to the attention of the general public as directors of institutions, mediators, or distributors. They frame the opinion of audiences by sharing their own opinions as critics, they shape and produce symbolic capital. Moreover, they may even create encounters in order to trigger the production of a fruitful artistic project (Lingo \& O'Mahony 2010). In doing so, they create the cultural frame in which symbolic goods are to be understood as legitimate, meaningful, or worth of interest. However, what they don't do is modifying directly the material shape of artworks. This work is handled by "support personnel," or tech crews: cameramen, editors, stagehands, or sound engineers.

This group is de facto excluded from this "cultural mediation," as their role does not grant the power to create market access. This particular mode of exclusion in cultural production been noted by David Hesmondalgh (2006), who called for a more inclusive frame under the label of "project team." David Wright (2005) aimed to capture this distinction by separating the "makers of meaning" from the "makers of things." While cultural intermediaries belong in the 
dans la première catégorie, la seconde est plus adaptée à décrire le travail des techniciens.

Nous proposons ainsi de concevoir les techniciens comme une entité différente des intermédiaires culturels. Nous nous intéresserons à eux comme membres d'une catégorie à part entière, les « intermédiaires techniques ». À l'instar des intermédiaires culturels, ils participent de la médiation de l'œuvre, mais sur un mode différent. Les intermédiaires techniques forment un chaînon entre le travail artistique, produit par les artistes, et le public. Leur action est de transformer la forme matérielle des œuvres d'art. Contrairement aux intermédiaires culturels, ils ne rajoutent pas de signification supplémentaire, c'est-à-dire de légitimité, de cadre d'interprétation, ou de "buzz », mais ils y joignent une dimension matérielle qui n'est pourtant pas exempte de signification symbolique. Ainsi, les intermédiaires culturels et techniques travaillent en toute complémentarité. Les premiers tentent d'insérer l'objet culturel au sein d'une grille culturelle et économique plus vaste afin de lui faire toucher un public, sans toutefois modifier directement son contenu matériel, tandis que les seconds travaillent directement sur les propriétés matérielles afin de s'assurer que le bien symbolique soit conforme à la fois à la vision esthétique de l'artiste, aux besoins de l'intermédiaire culturel et, idéalement, au goût du public.

\subsection{Objets et environnements au sein de la vie sociale}

Dans leurs missions, les intermédiaires techniques doivent travailler au contact d'objets, entités que le champ de recherche connu sous le nom de théorie de l'acteur-réseau considère comme des actants sociaux (Akrich, Callon, Latour 2006 ; Law 2009). L'une des particularités contestées de cette théorie, qui joue un rôle central dans son architecture, est de considérer que les objets, les environnements, les humains, les animaux et les former category, the latter more accurately fits the work of technical crews.

Hence, we propose to see technical crews as distinct from cultural intermediaries. Instead, we will investigate them as a category in itself, that we call "technical intermediaries." Like cultural intermediaries, they are involved in mediation, but their mediation is of a different nature. Technical intermediaries forge a link between the artistic work, as created by artists, and the audience. They do so by transforming the material shape of artworks. In contrast with cultural intermediaries, they do not add meaning -in the sense of legitimacy, framing, or "buzz"-but they add something material, that is nonetheless carrying symbolic meaning. Hence, cultural and technical intermediaries work in a complementary way. The former attempt to insert the cultural object in a larger cultural and economic frame in order for it to reach an audience, but without directly modifying the material content. The latter, on the other hand, work directly on material properties to ensure that the symbolic good will match both the artist's aesthetic views, the cultural intermediaries' needs - and ideally, the audience's tastebuds.

\subsection{Objects and Environments in Social Life}

In their tasks, technical intermediaries have to deal with objects, which in the field typically summarized as "Actor network theory," are framed as social actants (Akrich, Callon, Latour 2006; Law 2009). One notable and contested characteristic of this conceptualization, that is central to the theoretical architecture of ANT, is that objects, environments, humans, animals, and ideas all equally take part in a network of interactions. This "generalized symmetry" (Callon 1984; 
idées prennent tous part de façon égale à un réseau d'interactions. Cette « symétrie généralisée " (Callon 1986 ; Law 2009) porte à concevoir le monde social comme une série d'associations entre actants, c'est-à-dire des humains, des non-humains et même des

symboles qui forment des assemblages en évolution constante. Cette approche tend à invalider les analyses macrosociologiques, estimant que la société se construit et se démantèle entièrement au niveau micro (Latour 2006, Law 2009). Cette particularité lui a valu certaines critiques, notamment celle d'adopter une approche ontologique biaisée (Elder-Vass 2015 ; Lettow 2017), minimisant l'influence de facteurs institutionnels et l'évolution historique des rapports de pouvoir, tout en produisant des explications du social en réalité « supra-sociales » (Lettow 2017 : 112). Le concept de symétrie généralisée est au cœur de cette controverse, en ce qu'il implique une forme de flou dans la définition des aptitudes empiriques des actants. Dave Elder-Vass critique ainsi l'application de la définition classique de la symétrie généralisée de Michel Callon, qui établit une symétrie entre l'agentivité des humains et celles des coquilles Saint-Jacques :

Certaines des autres tentatives de Callon de traiter de façon symétrique les coquilles Saint-Jacques et les pêcheurs sont pour le moins étranges [...]. Par exemple : "En effet, c'est avec les coquilles que nos trois chercheurs doivent mener leurs négociations les plus dures et les plus longues" (Callon 1986 : 190). [...] Latour adopte également cette forme de symétrie. [...] sur un plan littéraire, de telles métaphores sont stimulantes. En tant que dispositifs provocants visant à pousser la pensée sociologique conventionnelle à reconnaître ses failles, elles sont efficaces. Mais en tant que bases méthodologiques d'un travail sociologique, elles sont profondément incorrectes. Les coquilles Saint-Jacques ne négocient pas, elles ne représentent ou ne trahissent personne. Les moteurs ne s'intéressent pas à des projets,
Law 2009) leads to a conception of the social world as a series of associations between actants, i.e. humans, non-human and even symbols that form constantly evolving assemblages.

This approach tends to invalidate macro-sociological analysis, stating that society is built and dismantled fully at a the micro level (Latour 2005; Law 2009). It has been criticized for doing so, and accused of promoting a biased ontological approach (Elder-Vass 2015; Lettow 2017) that minimizes the influence of institutional factors and historical relations of power, while providing explanations of the social that are, in fact, "supra-societal" (Lettow 2017: 112). The notion of generalized symmetry is at the center of this controversy, as it implies a form of fuzziness in the definition of actants' empirical abilities. For instance, Dave Elder-Vass comments on Michel Callon's classical formulation of generalized symmetry that highlights the symmetrical agency of humans and scallops:

Some of Callon's other attempts to treat scallops and fishermen symmetrically are frankly bizarre [...]. For example: 'In fact, the three researchers will have to lead their longest and most difficult negotiations with the scallops' (Callon, 1984); [...] Latour, too, adopts this sort of symmetry [...]. As a literary device, such metaphors are stimulating. As a device for provoking the recognition of a gap in conventional sociological reasoning, they are effective. As a methodological requirement for sociological work, they are thoroughly misguided. Scallops don't negotiate, represent, or betray. Motors don't become interested in projects or allow or forbid anything. [...] But scallops have different causal powers from humans, and different causal powers from motors. Scallops have the power to attach themselves 
ils n'autorisent ou n'interdisent rien [...]. En revanche, les coquilles Saint-Jacques ont des capacités d'action différentes de celles des humains, et de celles des moteurs. Les coquilles Saint-Jacques ont la capacité de se fixer aux rochers, ou aux collecteurs utilisés par le chercheur ; elles n'ont pas la capacité de négocier. Les moteurs peuvent actionner des véhicules dans certaines conditions (et pas d'autres), mais ils n'ont pas la capacité d'être intéressés, d'autoriser ou d'interdire. (Elder-Vass 2008 : 468-469.)

Nous affirmons que le concept d'intermédiaires techniques constitue une opportunité de renouveler l'approche de la problématique de l'agentivité des objets, ainsi que de la symétrie généralisée. Pour cela, nous prenons pour point de départ de récentes tentatives d'inclure les objets au sein de la sociologie de l'art, et en particulier chez Fernando Domínguez Rubio $(2012,2014,2016)$ qui évoque l'importance essentielle de « l'équipe ». Par exemple, dans la production de l'œuvre de Land Art Spiral Jetty (2012), « l'équipe » est indispensable pour résoudre les problèmes pratiques posés par un environnement plutôt hostile à la créativité de l'artiste Robert Smithson. L'équipe permet de réussir la production de l'œuvre, en dépit du terrain boueux, salin et isolé choisi pour la construction. Dans son travail qui parle de la « docilité » ou de l'« indiscipline » des œuvres du musée d'art moderne de New York, Fernando Domínguez Rubio souligne le rôle des restaurateurs : ils utilisent un éventail de technologies pour effacer les marques que la décomposition des objets fait apparaître plus ou moins rapidement (2014). À la suite de Howard Becker (1982) et de Steven Shapin (1989), il invite à s'intéresser aux « agents de nettoyages, plombiers, mécaniciens ou restaurateurs, responsables d'un travail indispensable à la maintenance quotidienne des objets sans lequel ces objets, de même que le système de significations et de valeurs dans lequel ils s'insèrent, s'effondreraient devant nos yeux » (Domínguez Rubio 2016 : 82). to rocks or to collectors used by the researcher; they do not have the power to negotiate. Motors have the power to drive vehicles in certain conditions (but not in others); they do not have the power to be interested, to allow, to forbid. (ElderVass 2008: 468-469.)

We argue that the concept of technical intermediaries offers an opportunity for a renewed approach of the problem of material agency and generalized symmetry. To do so, we build on recent attempts to integrate objects into the sociology of the arts, in particular by Fernando Domínguez Rubio $(2012,2014,2016)$ who mentions the central importance of "the crew." For instance, in the production of the landscape artwork Spiral Jetty (2012), "the crew" is indispensable to practically solve the problems posed by an environment rather hostile to artist Robert Smithson's creativity. The crew allows the successful production of the artwork, despite the muddiness, salinity and isolation of the place where it was built. In his work on "docility" or "unruliness" of artworks at MoMa, Fernando Domínguez Rubio highlights the role of conservators in this process: they use an array of technologies to erase the marks of the more or less fast object decomposition (2014). Following Howard Becker (1982), and Steven Shapin (1989), he calls to focus on "cleaners, plumbers, mechanics or conservators, who are responsible for the critical work through which objects are sustained on a daily basis, and without which these objects, as well as the systems of meanings and value that are woven through them, would simply collapse in front of our eyes" (Domínguez Rubio 2016: 82). 
Fernando Domínguez Rubio montre comment un travail humain est nécessaire aux associations entre objets, humains et significations. II s'intéresse à ceux qui travaillent la matière afin de lui donner une signification voulue : des constructeurs dans le cas de Spiral Jetty, des restaurateurs dans le cas du MoMa. Ces personnes sont précisément des intermédiaires techniques. Toutefois, Fernando Domínguez Rubio adopte le cadre de la symétrie généralisée et conçoit les objets comme des actants actifs dans le procédé de production du sens. Il décrit par exemple avec force détails l'éventail de dispositifs et de technologies utilisées pour la conservation de La Joconde. Par conséquent, il conceptualise le travail des intermédiaires techniques comme une réaction aux actions des objets, plutôt que comme une action sur les objets

[E]n tant que choses, les œuvres d'art dérivent constamment des rôles d'objets auxquels on les assigne. [L]es restaurateurs ont attaché un dispositif
de mesure prothétique $[. .$.$] qui enregistre$ quotidiennement le comportement de la peinture. (Domínguez Rubio 2016 : 78. Nous soulignons.)

Cette approche a pour résultat de faire disparaître les intermédiaires techniques du tableau : qui sont-ils ? Quels sont leurs parcours ? Comment sont-ils intégrés dans leurs environnements de travail ? Mais surtout, comment les réponses à ces questions influencentelles leur capacité à créer ou à maintenir la forme dont les objets tirent leur signification? Pour répondre à ces questions cruciales, il est nécessaire de renverser la perspective, en se focalisant sur les parcours et les comportements des intermédiaires techniques plutôt que sur les matières sur lesquelles ils travaillent. Ce faisant, nous remettons en question la pertinence de la symétrie généralisée, en affirmant que l'on ne peut pas comprendre ces questions en s'intéressant indifféremment aux objets ou aux humains. Ainsi, dans cet article, nous présumerons que les contributions des
Fernando Domínguez Rubio shows that associations between objects, humans and meanings require human work. He identifies people that shape the matter in order to give it an intended meaning: builders in the case of Spiral Jetty, conservators in the case of the MoMa. These people are, in fact, technical intermediaries. However, following the assumption of generalized symmetry, Fernando Domínguez Rubio's analysis eventually focuses on materials framed as active actors in the meaning production process. For instance, he describes in much detail the array of devices and technologies used for the conservation of the Mona Lisa. He therefore conceptualized the work of technical intermediaries as a response to the actions of objects, rather than as action on the objects:

[Q]ua things, artworks are constantly veering away from the object-positions to which they are subsumed. [C]onservators attached a prosthetic measuring device [...] that record the daily behavior of the painting. (Domínguez Rubio 2016: 78. Authors' emphasis).

As a result, technical intermediaries themselves escape from view: who are these people? What are their trajectories? How are they integrated in their working environments? Most importantly, how do the answers to these questions influence their ability to create or maintain the shape in which objects are meaningful? These central questions can only be answered by reversing the perspective: starting from the technical intermediaries' trajectories and behaviors rather than from the materials they are working on. In itself, this calls into question the accuracy of generalized symmetry, as it suggests that these issues cannot be understood by indifferently focusing the analysis on objects or humans. In this article, therefore, we assume that objects and human contributions 
humains et des objets à la production des significations culturelles sont qualitativement différentes, ce que nous vérifierons de façon empirique.

\section{3. Étudier les intermédiaires techniques}

En dépit du rôle central joué par ce type d'acteurs dans une production culturelle contemporaine très dépendante de la technologie, les intermédiaires techniques ont fait l'objet de peu de recherches dans la littérature actuelle. Des travaux ethnographiques sur leurs pratiques professionnelles au sein de différents champs artistiques existent bien (Horning 2004 ; Kealy 1979 ; Kuipers 2015 ; Le Guern 2004 ; Leyshon 2009 ; Perrenoud 2007 ; Rudent 2008), mais ont donné lieu à peu de théorisation.

Le travail de Stephen Barley (1996) constitue à cet égard une exception. Utilisant une perspective de sociologie des organisations, ce dernier est parvenu à démontrer que les techniciens issus de différents environnements professionnels (mondes de l'art ou non) partageaient des pratiques professionnelles similaires. Le travail technique se divise en une part relationnelle et une part non relationnelle. Cette dernière touche à la production de représentations symboliques du comportement des systèmes mécaniques, électriques ou biologiques. L'aspect relationnel consiste à faire correspondre ces représentations avec les attentes de leurs collègues de travail. Cette distinction servira de fil conducteur à notre analyse d'un groupe particulier d'intermédiaires techniques : les ingénieurs du son.

\section{Méthode : observation des pratiques de travail des ingénieurs du son}

Afin d'analyser le travail relationnel et non relationnel des intermédiaires techniques, il nous faut étudier le travail de ces in the production of cultural meaning are of a qualitatively different nature, and we will verify this assumption empirically.

\subsection{Studying Technical Intermediaries}

Despite arguably being a central type of actor in contemporary, technology-driven cultural production, technical intermediaries have been the object of little research in the current literature. Although ethnographic accounts of their working practices in different art worlds do exist (Horning 2004; Kealy 1979; Kuipers 2015; Le Guern 2004; Leyshon 2009; Perrenoud 2007; Rudent 2008), very little conceptual work has been done so far.

A notable exception is Stephen Barley (1996). Working from the perspective of organizational sociology, he showed that technicians across various working environments, art worlds or otherwise share similar working patterns. Technical work is divided in a relational and a non-relational part. The latter regards to production of symbolic representations of the behavior of mechanical, electric or biological systems. The other aspect is relational and consists in making these representations fit the expectations of their coworkers. This distinction will guide our analysis of the work of a particular group of technical intermediaries: sound engineers.

\section{Method: Shadowing Sound Engineers}

To analyze the relational and non-relational work of technical intermediaries, we need to study the work of technical intermediaries 
derniers au sein d'un domaine où leur contribution est essentielle et visible. C'est le cas de la musique live actuelle. De nombreux concerts, quel que soit le genre, le lieu ou la jauge, nécessitent l'utilisation d'un système de sonorisation. Aucun musicien pop ne pourrait se produire dans un stade sans sonorisation. Un concert rock dans une petite salle n'a pas le même effet si la voix est couverte par la batterie et les amplis guitare. Le système de sonorisation est toujours assemblé, géré et démonté par des techniciens du son, le groupe professionnel auquel nous allons nous intéresser ${ }^{1}$

Entre décembre 2015 et mars 2018, le premier auteur de cet article a mené dix-huit entretiens avec des techniciens du son dont seize travaillaient (au moins en partie) dans la musique live. Seize d'entre eux vivaient à Paris ou en région parisienne, un en région lyonnaise et un à Montréal. Les entretiens avaient pour objectif de récolter des informations sur leurs trajectoires sociales avant et après leur carrière, sur l'état actuel de leur carrière et sur leurs pratiques et éthiques professionnelles (voir la liste des personnes interrogées en annexe)

Nous avons ensuite suivi onze d'entre eux au cours de vingt observations de concert et musique live, au cours desquelles nous avons examiné leurs tâches et leurs interactions avec d'autres acteurs. Nous avons également récolté des informations sur le lieu de concert et ses pratiques grâce aux documents disponibles

1. Dans les petits concerts de «musiciens ordinaires» (Perrenoud 2007), i est possible qu'il n'y ait aucun intermédiaire technique et que la tâche de gérer le système de sonorisation soit pris en charge par les musiciens eux-mêmes. Ce cas particulier est resté hors de notre enquête, car nous sommes entrés sur ce terrain en nous intéressant aux intermédiaires techniques. Toutefois, dans ce cas, le travail des techniciens étant assuré par les musiciens, ces derniers endossent à la fois le rôle d'artistes et d'intermédiaires techniques. I existe donc des intermédiaires techniques dans les concerts de « musiciens ordinaires »: les musiciens eux-mêmes. in a field in which their contribution is crucial and visible. This is the case of contemporary live music. Many concerts, regardless of their genre, place or range, require the use of a public address (PA) system. No pop musician could play in a stadium without the use of amplifiers. A rock concert in a small venue would amount to nothing if the non-amplified voice was covered by the drum and guitar amps. The necessary PA system is always built, managed and dismantled by sound technicians - the professional group on which we are going to focus ${ }^{1}$.

Between December 2015 and March 2018, the first author conducted eighteen interviews with sound technicians, sixteen of which working (at least partly) in live music. Sixteen were working and/or living in Paris and its suburbs, one in the region of Lyon (France), and one in Montréal, Canada. The interviews aimed to gather information about their social trajectories before and during their career, the current state of their career, and their professional practices and ethos (see the list of respondents in annex).

We have then followed eleven of them in twenty observations of live music productions, in which we scrutinized their tasks and interactions with other actors of the concerts. We also gathered information on the venue and its working practices through available documents and informal discussions, and did interviews

1. In small concerts held by "ordinary musicians" (Perrenoud, 2007), there might be no professional technical intermediary, and the task of handling the PA system can be held by musicians themselves. This specific case is kept out of our scope, as we entered the field by focusing on technical intermediaries. However, in this case, the work that would be done by technicians being done by musicians, the latter endorse both the roles of artists and technical intermediaries. There are, thus, technical intermediaries in "ordinary musicians" concerts: the musicians themselves. 
sur place et à des conversations informelles, et nous avons mené des entretiens avec les musiciens quand cela était possible. Nous avons pu observer des contextes artistiques variés. Onze observations se sont tenues pendant des concerts uniques, qui n'étaient pas conçus pour se répéter dans la même salle. Cinq de ces concerts faisaient partie de tournées, les autres non. Certains étaient exécutés par des musiciens payés, d'autres jouaient gratuitement. Les autres observations ont été menées pendant un concours de danse hip-hop en journée, pendant l'enregistrement d'un concert de musique classique non amplifié, pendant une résidence de deux jours, et pendant trois pièces de théâtre faisant un usage important de musique live. Pour finir, nous avons observé deux festivals de plusieurs jours en plein air, l'un dans la position habituelle de chercheur observateur, l'autre en tant qu'assistant sur différentes scènes. Pendant l'intégralité de nos observations, nous avons ouvertement assumé une position d'observateur. Il est important de noter que le premier auteur a également une expérience professionnelle de technicien du son.

Malgré cette diversité, nous avons observé deux tâches systématiquement récurrentes. Le mixage, c'est-à-dire le fait d'équilibrer entre elles les sources sonores reprises des différents instruments, fait partie de ces tâches. L'installation du système de sonorisation est également une autre tâche partagée : le positionnement du système de sonorisation doit être mûrement réfléchi en fonction de l'acoustique du lieu. Même si les enceintes sont installées de façon permanente dans la salle, il est nécessaire de les calibrer, c'est-à-dire, de les accorder à la musique spécifique qui sera jouée en un jour donné. En nous appuyant sur les données de notre étude ethnographique, nous évaluerons les aspects relationnels et non relationnels de ces deux tâches. with musicians whenever possible. In doing so, we observed a variety of artistic contexts. Eleven observations were done during unique shows that were intended to not be repeated. Five of these were part of tours, the others were not. Some of them were done by paid musicians, others played for free. The other observations were done during a daytime hip-hop dance contest; the recording of a non-amplified classical concert; a two-day rehearsal; and three theater plays with ample use of live music. Finally, we observed two several-day open-air festivals, one in the usual position of observing scholar, the other one as a sound assistant on different stages. In all our observations, we openly assumed an observer position. Note that the first author also has experience working as a sound technician.

Despite this diversity, two tasks are shared by all the observed performances. Mixing, i.e. balancing the sources of captured sounds of the different instruments, is one of these tasks. The installation of the PA system is another common task: a PA system positioning has to be carefully thought through-regarding the acoustics of the venue. However, even if the speakers are permanently installed in the venue, the system has to be calibrated, i.e. tuned for the specific music that will be played on a given day. Using the data of our ethnographic study, we will gauge the relational and nonrelational aspects of these two tasks. 


\section{La médiation technique relationnelle : changer les propriétés matérielles de la musique}

On pourrait interpréter le travail des ingénieurs du son sur la musique live comme une transformation de la musique, un bien symbolique, en son, un objet physique. Si la musique est décrite en termes de représentations, de références culturelles, de subjectivités, d'identités, etc., le son se conçoit en termes physiques : unités de pression acoustique, intensité du signal électrique et autres indices physiques. Ces symboles deviennent visibles sur une console de mixage et sont manipulés par le technicien qui siège derrière : les vumètres et les écrans fournissent des mesures des propriétés physiques du son, tandis que les boutons et les faders offrent la possibilité de modifier ces propriétés. Le rôle de l'ingénieur du son qui mixe est d'interpréter et de rectifier ces informations.

\section{Relational Technical Mediation: Changing Material Properties of Music}

One way to interpret live music sound technicians' work is to say that they transform music, a symbolic good, into sound, a physical object. While music is described in terms of representations, cultural references, subjectivities, identities and so on, sound is described in physical terms: units of acoustic pressure, intensities of electric signal, and other physical descriptions. These symbols become visible on a mixing desk, and are handled by the technician behind it: vu-meters and screens provide measures of the physical properties of sound, while knobs and faders provide the possibility to change these properties. Interpreting and modifying this information is the role of the mixer.

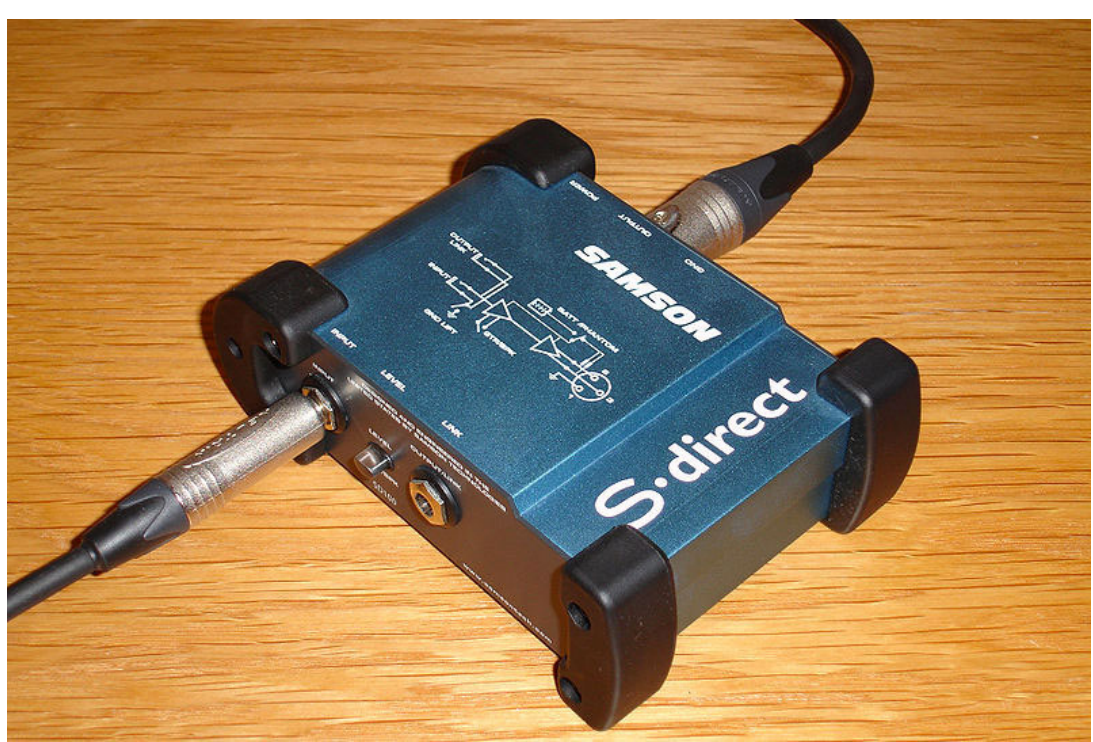

Fig. 1. Boîtier d'injection directe / Fig. 1. DI box (c) Bene Source : Wikimedia Commons 
D'un point de vue strictement physique, le son qui atteint le public n'est pas le même que le son produit par les musiciens. L'intervention du mixeur a pour but de produire un son qui soit reconnu comme la musique interprétée par les artistes. Nous verrons que l'aspect relationnel du travail du technicien est crucial pour parvenir à cet objectif.

Pour la part non relationnelle, la transformation opérée par les ingénieurs du son sur la musique fonctionne en trois étapes. Ils captent, puis retouchent avant de restituer la musique. La musique est captée par des microphones ou des boîtiers DI dans le cas de sources électriques (voir figure 1). Les ingénieurs du son se servent ensuite de différents outils, comme une console de mixage, afin de modifier la musique captée. Nous désignons cette étape comme la retouche. Après modification, la musique est restituée par des haut-parleurs. Cette restitution se déroule simultanément sur deux plans. Pour le public, le son est rendu à un volume plus élevé que ce que pourraient produire les musiciens seuls : il s'agit du son de façade. Les musiciens sur scène ont également besoin d'avoir leur propre son, le son des retours ou son de scène. Le chemin parcouru par le son, depuis l'instrument du musicien jusqu'à ses oreilles et à celles du public s'appelle la chaîne audio. La figure 2 montre cette chaîne dans son intégralité. La chaîne audio est le procédé par lequel les propriétés matérielles de la musique vont être transformées afin de recevoir leur forme finale, telle qu'elle sera reçue par le public (son façade) et par les musiciens (son retour).

Cette forme finale s'appelle une image audio.
In a strictly physical sense then, the sound that reaches the audience is not the same as the sound made by the musicians. The mixer's intervention aims to produce a sound that is nonetheless recognized as the music performed by artists. We will see that the relational aspect of technician's work is central to achieve this goal.

On the non-relational side, sound technicians proceed in three steps to perform the music's transformation. They capture, retouch and eventually restitute music. Music is captured by microphones, or DI boxes in the case of an electric source (see Figure 1). Sound technicians then use different tools, such as a mixing desk, to modify the raw piece of captured music. We call this step retouch. After being modified, music is restituted on speakers. Two restitutions happen at the same time. For the audience, the sound is restituted at a louder volume than what can be attained by musicians alone: this is the front of house sound. Musicians on stage also need a sound of their own, the monitor or stage sound. The whole path of the sound, from the musicians' instruments to their ears and those of the audience, is called the audio chain. Figure 2 shows this entire chain. This audio chain is the process through which material properties of music are transformed to take their final shape, in which it will be received by the audience (front of house) and musicians (monitor). This final shape is called an audio image. 

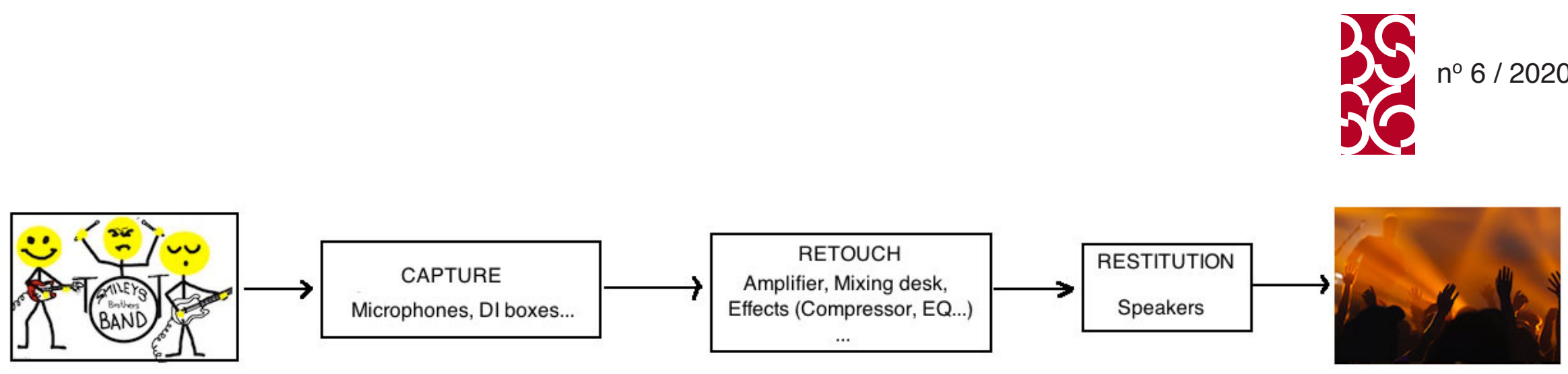

Fig. 2. Schéma de la chaine audio, d'après Mercier 2017 / Scheme of the audio chain, based on Mercier 2017 Sources : à gauche, dessin du groupe de musique par Dunive ; à droite, photo d'Edward Cisneros ; montage de l'auteur / on the left, drawing of the music group par Dunive; on the right, picture by Edward Cisneros; editing by Andy Battentier.

Loin d'être neutre et évidente, la transformation de la musique en son ne saurait être réduite à une simple augmentation des pressions acoustiques, et ce pour plusieurs raisons. La première touche aux propriétés physiques du son. En effet, la perception humaine de la pression acoustique ne se fait pas selon une logique proportionnelle, mais logarithmique. Cela signifie que dans certaines plages de valeurs, des changements minimes peuvent avoir des conséquences très significatives, tandis que dans d'autres plages de valeurs, des changements importants peuvent avoir des conséquences minimes. Ainsi, pour obtenir une image audio qui offre une augmentation proportionnelle du volume de la musique, les techniciens doivent recourir à une variété de filtres et d'outils, comme le gain, qui amplifie le signal d'une source audio, ou l'égalisation, qui valorise ou coupe certaines fréquences du spectre sonore.

Cependant, les outils des techniciens ont leurs limites. Par exemple, si un micro et un haut-parleur sont trop proches, le son du hautparleur peut être repris par le microphone, réamplifié puis repris à nouveau produisant un effet Larsen (Mercier 2017). La boucle de reprise/réamplification continuant à se répéter, le son augmente progressivement jusqu'à atteindre le maximum des possibilités du système et peut provoquer sa destruction. Le son est également
Far from being plain and neutral, this transformation cannot be assimilated to a direct and simple raising of acoustic pressures, for several reasons. The first one has to do with the physical properties of sound. Indeed, human perception of acoustic pressure does not follow a proportional logic, but a logarithmic one. This means that in certain value ranges, slight changes have a big impact, while in other ranges, the impact is limited even in the case of big changes. Thus, in order to obtain an audio image that resembles a proportional raise in the volume of the music, technicians have to apply a range of filters and tools, such as gain, which amplifies the signal of an audio source, or EQ, which boosts or cuts frequencies within the audio spectrum.

However, the tools of technicians come with limitations. For instance, if a microphone and a speaker are too close, the speaker's sound can be taken over by the microphone, reamplified, taken back again, creating what is commonly known as "feedback" or the "Larsen effect" (Mercier 2017). As the loop goes on, sound raises progressively up to the maximum of the system's possibilities, and 
très déplaisant pour l'oreille humaine, et les techniciens travaillent généralement à l'éviter.

Ainsi, les propriétés physiques du son et du traitement du signal impliquent une transformation qui n'a rien de neutre. Les différents outils qui une fois assemblés constituent le système de sonorisation (microphones, console de mixage, modules d'effets, câbles, amplificateurs, haut-parleurs...) permettent aux techniciens de prendre en charge la sonorisation tout en tenant compte des modifications spécifiques que ces propriétés physiques supposent. Toutefois, la façon dont ces outils vont être utilisés est assez peu déterminée par les propriétés matérielles de la musique. Elle est davantage modelée par le type de relation entre les musiciens et les techniciens, comme nous allons le voir en nous intéressant de plus près à la création du son façade.

Notre recherche de terrain nous a confrontés à différents niveaux de proximité entre les musiciens et les techniciens au cours d'un concert. Cependant, ces différents degrés peuvent être conçus comme une gamme de possibilités contenues entre deux relations archétypales. La collaboration très ponctuelle, lorsqu'un technicien est embauché par une salle pour installer le système de sonorisation et faire le son d'un groupe qu'il n'a jamais rencontré représente l'un de ces archétypes. La collaboration à long terme reposant sur des affinités - le technicien connaît l'artiste depuis longtemps et est profondément engagé dans les questions artistiques - constitue l'autre archétype. Nous nous intéresserons à ces deux archétypes, pour le contraste qu'ils nous offrent.

Dans tous les cas de figure, l'image audio suppose une reconstruction intégrale de la musique. Marc Perrenoud (2007) décrit comment l'enregistrement est une étape cruciale dans la formation des jeunes musiciens. En effet, le choc provoqué par la can cause its destruction. The sound is also generally unpleasant to the human ear, and technicians generally avoid it.

Hence, physical properties of sound and signal treatment imply first and foremost a non-neutral transformation. The various tools that assembled, form a PA system (microphones, mixing desk, effects modules, cables, amplifiers, speakers...) allow technicians to handle amplification while accounting for the specific kind of changes that these physical properties implies. However, the way these tools are used are in fact scarcely driven by the material properties of the music. Rather, it is shaped by the type of relationship that emerges between musicians and technicians, as we will see now by looking closer on how the front of house sound is constructed.

Our fieldwork showed diverse degrees of closeness between musicians and technicians for a live show. However, these degrees can be summarized as a range bounded by two archetypes: one extreme case is the completely one-time collaboration, when a technician is hired by a venue to settle a PA system and do the sound of a band he never met before. The other extreme is the long-term collaboration based on informal kinship, in which the technician knows the artists beforehand and is deeply involved in artistic matters. For the sake of contrast, we will focus on the two archetypes.

In all cases, the audio image entails a full reconstruction of the music. Marc Perrenoud (2007) described how recording was an important step in the formation of young musicians, as the shock provoked by the contrast between what is heard in rehearsal and 
grande différence entre ce que l'on entend en répétition et ce que l'on entend en enregistrement représente un défi pour l'identité du musicien. Dans tous les cas, ce sont des ingénieurs du son qui se chargent de cette reconstruction.

Dans le cas des collaborations de longue date, les ingénieurs du son jouent le rôle d'oreille extérieure guidant les musiciens dans la reconstruction de leur image audio. Leur rôle peut alors s'approcher de la direction artistique :

«Au premier concert que je fais avec eux, je fais "waow, catastrophe" [...] il y avait plein de problèmes de son, d'arrangements, de... mise en place, il y avait des trucs qu ne prenaient pas [...]. Tous les ingés ne sont peut-être pas forcément comme ça, mais moi j'ai beaucoup de ressenti, quoi. Et quand moi je ne suis pas bien, c'est que ca ne va pas. Du coup, au début, je suis un peu perdu et je me dis merde... va falloir qu'on fasse quelque chose. Donc on commence à rentrer dans une discussion, et puis à faire évoluer le problème $[. .$.$] . » (B, entretien.)$

Cette citation illustre la façon dont le technicien ne puise pas seulement dans son expertise technique mais également dans sa propre conception esthétique pour prodiguer des conseils et utiliser correctement les outils permettant de construire l'image audio. Cette collaboration de nature à la fois artistique et technique

s'inscrivait dans un procédé de réalisation d'un projet artistique.

« Z : - Tu leur donnes des retours de direction artistique en fait..

B : - Ouais, voilà, ouais. Et pas seulement. C'est parfois purement technique, mais c'est aussi artistique : ils le savent très bien, et ils ont été hyper preneurs de ça. Du coup, sur la route, au fur et à mesure des dates, on va... ils vont what is heard in recording constitutes a challenge to the musicians identity. Sound engineers, in all cases, have to handle this reconstruction.

In the case of a long-term collaboration, sound engineers work as an external ear guiding musicians into the construction of their audio image. Their role can then be close to the one of artistic directors:

"The first concert I did with them I said 'wow, catastrophe' [...] it was full of sound problems, arrangements... stuff that did not work [...]. Maybe not all sound engineers are like me but I really use the way I feel music. And if I am not feeling well, it means it does not work. So at the beginning I am a bit lost and I said okay... we have to do something about this. So there, we start a discussion and to make the problem evolve [...]." (B, interview.)

This quote illustrates how the technician does not only draw on his technical expertise, but also on his personal sense of aesthetics to provide advice and to properly use the tools for constructing the audio image. This collaboration was part of the process of achieving an artistic project, that was both artistic and technical:

"Z: - In fact you were giving them artistic feedback.

B: - Yeah. But not only. Sometimes it is purely technical but also artistic. They know it and they have really been receptive to it. So on the road, step by step, gig after gig, we will... they will modify stuff... they were also in a research of sound. [...] what is interesting for me is to participate in the 
modifier des trucs, ils vont... Alors ils étaient aussi dans une recherche de son [...]. Ce qui m'intéresse, c'est de participer à cette évolution d'un groupe. Tu vois, de... Voilà, c'est hyper intéressant. » ( $B$, entretien.)

Cette collaboration peut être cruciale dans la construction de l'identité musicale d'un groupe. L'un des groupes observés, par exemple, jouait sur des instruments acoustiques, mais en ayant l'intention de les faire sonner comme des instruments électroniques. Dans ce cas, le rôle de l'ingénieur du son est crucial, car l'illusion repose sur les transformations qu'il opère en direct. Ici, l'utilisation d'outils technologiques permet de répondre à ces conventions esthétiques. Par exemple, nous avions remarqué pendant notre observation que deux microphones étaient pointés sur certains instruments. Ces deux microphones avaient deux sensibilités différentes et étaient utilisés selon le style de jeu du musicien, afin que l'instrument sonne de façon électronique.

« Le batteur joue avec différentes sortes de baguettes sur la caisse claire, de plein de façons différentes... Sur certaines parties du set je sais qu'il va jouer fort, alors j'utilise le dynamique. Sur d'autres morceaux il va y aller plus doucement, alors j'utilise le statique. » $(\mathrm{H}$, conversation pendant l'observation.)

Mettre en place ce type de dispositif demande beaucoup de temps et d'effort. Dans ce cas particulier, le projet repose sur plusieurs conditions historiques. Le technicien et les musiciens s'étaient rencontrés à l'école dix ans auparavant et travaillaient ensemble depuis lors. Cela leur avait permis de développer une esthétique particulière qui impliquait pleinement le technicien. Symbole de ce lien, il était connecté aux musiciens en portant lui aussi un costume de scène, même s'il travaillait depuis la salle. Il était complètement evolution of this band, you see." (B, interview.)

This collaboration can be central in the construction of a band's musical identity. For instance, one of the observed bands played acoustic instruments, but with the intention of making it sound like electronic ones. The role of the sound engineer, in this case, is crucial, as it is through the transformation he sets in motion that the illusion is built. In this case, the use of technological tools is driven by specific aesthetic conventions. For instance, we noticed during the observation that two microphones were pointed at some instruments. In fact, these two microphones had different sensitivities, and were used according to the playing style of the musician, in order to make the instrument sound in an electronic way:

"The drummer plays with all kinds of sticks on the snare, in all kinds of ways... On some parts of the set, I know that he will play loud and so I use the dynamic microphone. On other tunes, I know he will be soft so I use the static." $(\mathrm{H}$, small talk on the spot.)

This kind of precise setting requires a lot of time and effort. In this particular case, the project required several historical conditions. The technician and musicians met at school around ten years ago, and had been working together since. This allowed them to develop a specific aesthetic in which the technician is completely involved. As a symbol of that, he was linked with the musicians during the representation by wearing a stage costume, although he was working from the room. He became completely integrated into the 
intégré au groupe, au point qu'en son absence, il était impossible au groupe de jouer.

«Par exemple, avec eux [ce groupe] j'ai créé le truc qui fait que, si je ne suis pas là, ils ne peuvent pas faire de concert. [...] Je pense que ce qui m'a plu dans ce métier, c'était ça en fait. C'était de faire partie du projet artistique. Et la conséquence, c'est justement d'être irremplaçable, quoi. » $(H$, entretien.)

Cette intégration déborde de l'aspect artistique du travail et implique sa participation aux négociations entourant les concerts

du groupe :

«Quand je traite avec le régisseur ou la régisseuse, je dois défendre le projet : "Oui, on a vraiment besoin d'un piano, non, on va pas mettre un piano numérique parce que le mec gratte les cordes, donc un piano numérique, ca va pas le faire." Avec le manager : "Oui, on a vraiment besoin de mettre les demandes des musiciens, oui on a vraiment besoin de faire venir l'ingénieur son parce que c'est indispensable." Ce genre de trucs. Oui, on a vraiment besoin de faire deux heures de balances... Avec les musiciens : "Oui, on a vraiment besoin d'être concentrés sur scène parce que nous, on joue vraiment, on ne joue pas avec des machines [...] donc on ne va pas faire le show, non, on ne va pas aller courir dans le public". » (H, entretien.)

Sa capacité à négocier de cette façon est conditionnée par le soutien des autres participants du projet, qu'il s'agisse des musiciens ou des intermédiaires culturels.

"On est tous concernés par l'originalité de ce projet. Et ça, c'est quand même vraiment cool : c'est-à-dire que tu ne band, to the point that his absence would result in the impossibility for the band to play:

"For instance with them [this band], I've created the thing that if I am not here, they can't do a concert. [...] I think this is what I liked in this job in fact. Being part of the artistic project. And the consequence of that is precisely to be irreplaceable." $(\mathrm{H}$, interview.)

This integration goes far beyond the artistic side of the work, and implies his participation to the negotiation of the band's gigs:

"When I negotiate with the venue's technician, I need to defend the project: 'Yes, we need a piano, no, we are not putting a keyboard because the guy scratches the strings so a digital keyboard is not gonna work.' To the tour manager: 'Yes we really need to give musicians what they say they need, yes we really need to bring our sound engineer because it's essential.' These kind of things. Yes we really need two hours of soundcheck... To the musicians: 'Yes we really need to be focused on stage because we really play, we don't play with machines [...] so no we are not going to make a show, we will not run in the audience."' $(\mathrm{H}$, interview.)

The ability for him to negotiate in this way is conditioned by the support of other people involved in the project, whether they are musicians or cultural intermediaries:

"We are all committed to this project's originality. And that's really cool, that you don't find yourself alone, defending 
te retrouves pas tout seul à devoir défendre des desiderata d'artistes, mais qui n'ont pas conscience d'être en marge, face à une prod qui... la prod de ton groupe, je te parle, qui elle se range du côté des programmateurs et qui dit: "Mais attends, tout le monde nous dit que c'est aberrant, pourquoi est-ce qu'on le fait, quoi ?" » (H, entretien.)

On peut donc voir que si l'identité musicale spécifique de ce groupe est permise par la technologie, le travail sur le son qui permet à cette identité d'émerger est essentiellement le produit des relations construites entre les participants aux projets. Dans ce cas, les musiciens et le technicien se connaissent depuis plusieurs années. Mais comment se produit la reconstruction de l'image audio lorsque les techniciens et les musiciens ne se connaissent pas ? L'absence de relation forte conduit-elle les aspects matériels

à prendre le relais et à imposer leur définition de la situation?

Lorsqu'ils ne se connaissent pas au préalable, les musiciens et les techniciens doivent établir une relation lors de ce qu'on appelle " la balance », le moment qui précède le concert où les musiciens montent sur scène et jouent pour que le technicien puisse régler le son. Dans cette configuration, l'aspect communicatif et relationnel de la balance est particulièrement visible, aucune routine de travail n'étant installée entre les musiciens et les techniciens. Si les musiciens ne donnent spontanément aucune information, les techniciens doivent demander toutes les informations nécessaires. Par exemple, lors d'une observation au cours d'un festival de trois jours en plein air, un groupe de cumbia de neuf personnes s'est présenté sur scène sans son ingénieur du son. Le leader du groupe, visiblement habitué à cette situation, a apporté une liste des chansons jouées au technicien une demi-heure avant le début du concert, en lui expliquant qui allait faire des solos et quand, et comment les percussions et les instruments mélodiques, ainsi que the desires of artists that aren't conscious that they are on the margins, with the managers of your band who fall in with the programmers and who says: 'But wait, everyone tells us this is nonsense, why are we asking this?"' $(H$, interview.)

We can see that if the particular musical identity of this band is allowed by technologies, the work on sound that makes this identity emerge is mostly driven by the type of relationship constructed among the insiders of the project. Musicians and technician, in this case, knew each other for several years. But how is the reconstruction of the audio image going when technicians and musicians don't know each other in advance? Does the absence of a solid relationship allow for the material to take over and "impose" its definition of the situation?

When they don't know each other beforehand, musicians and technicians have to establish a relationship during the so-called "sound-check," the moment before the concert when musicians get on stage and plays for the sound technician to settle the sound. In this configuration, the communicative and relational aspect of the soundcheck is particularly visible, as working routines are not settled between musicians and technicians. If the musicians are not giving information spontaneously, technicians have to ask for all relevant information. For instance, during an observation of a three days open-air festival, a cumbia big band brought nine persons on stage, and did not bring a technician with them. The leader of the band, visibly trained to this situation, brought a set list to the technician half an hour before the beginning of the show and explained to him who will play solos and when, how percussion and melodic instruments, as well as lead and choir voices should be balanced. In this case, the sound design is the result of a direct 
les voix principales, et les chœurs, devaient être équilibrés. Dans ce cas, le son obtenu est le résultat d'une négociation directe entre le musicien et le technicien, répondant à la logique « the show

$$
\text { must go on ». }
$$

À l'inverse, au cours de la même observation, un groupe s'est présenté sans technicien et n'a pas communiqué du tout avec l'ingénieur du son façade. Ils ont joué comme s'ils se trouvaient en répétition, et ont mis fin brutalement à la balance, sans prévenir. Ils ont ensuite quitté la scène, laissant les ingénieurs du son façade et retour avec un son à reconstruire totalement pendant les premières minutes du concert. La qualité sonore diminua en conséquence avant de s'améliorer progressivement pendant le concert.

Lorsqu'ils ne connaissent pas les musiciens, les techniciens ont quelques minutes pour saisir l'identité musicale du groupe, en se fondant sur les morceaux qui vont être joués pendant la balance. À l'exception de quelques modifications marginales et très habituelles, comme l'ajout de réverbération sur la voix, les techniciens ne s'autorisent généralement pas à changer la musique dans un but esthétique. Pour produire le son d'un groupe, ceux-c vont compter sur leur interprétation de la façon dont le groupe doit sonner, d'après ce qu'ils voient des musiciens sur scène, selon les informations préalables dont ils disposent, en fonction de leur propre expérience de techniciens, et bien évidemment en fonction de ce que leur disent les musiciens. Dans cette configuration, la communication et l'analyse des autres est la clé pour produire un son correct.

De multiples nuances existent entre les deux extrémités que représente la collaboration à long terme qui s'appuie sur une relation personnelle et la collaboration unique. Chaque variation negotiation between the musician and the technician, under the logic of "the show must go on."

In contrast, during the same observation, one of the bands came without a technician and did not communicate with the front sound engineer at all. They were playing as if they were rehearsing, and stopped the soundcheck suddenly and without warning. They then went off stage, leaving the front of house and monitor sound engineers with a sound that had to be completely rebuilt during the first minutes of the show. As a consequence, the sound quality dropped, but was only gradually improved during the performance itself.

When they do not know musicians, technicians have to grasp the musical identity of the band within a few minutes, on the basis of the tunes that will be played in the soundcheck. Except for marginal and very conventional moves such as putting a reverb on a voice, technicians usually do not allow themselves to change the music with an aesthetic purpose. To produce the sound of the band, they will rely on an interpretation of how the band is supposed to sound, according to what can be visibly expected of the musicians on stage, on the basis of the information they already have and according to their own experience as technicians, and of course on the basis of what the musicians tell them. In this configuration, communication and the "reading" of other persons is the key to producing the proper sound.

Multiple nuances exist between the two extremes of long-term collaboration based on informal kinship and unique one-time collaboration. Each variation leads to a differences in the material 
imprime une différence sur la forme matérielle par laquelle le public percevra la musique. Une autre situation récurrente est l'habitude de labels, managers ou autres intermédiaires culturels de faire appel à leur propre technicien, qui s'il ne connaît pas les musiciens au préalable peut ensuite s'inscrire dans une relation à long terme

avec eux.

Nous avons montré que la construction de l'image audio des musiciens sur scène dépend grandement du type de relation qu'ils entretiennent avec les techniciens, et également du niveau de communication entre eux. Les propriétés physiques du son, et les caractéristiques techniques des outils ne jouent qu'à la marge dans la poursuite de cet objectif. Toutefois, se poster derrière la console et mixer ne représente qu'une partie du travail technique de la musique live. Avant cela, parmi d'autres tâches, il faut sélectionner le système de sonorisation, l'assembler, et l'accorder à l'acoustique de l'environnement dans lequel il sera utilisé. Du fait de la nature plus matérielle de cette tâche, on peut raisonnablement s'attendre à ce que cette partie du travail soit davantage liée aux objets, aux environnements et aux outils.

\section{La médiation technique non relationnelle : produire un son homogène dans toute la salle}

Les images audio peuvent être conçues lors de répétitions ou en studio, loin de l'endroit dans lequel elles seront déployées. Ainsi les intermédiaires techniques d'une performance live, en plus de réaliser l'équilibre entre les différentes sources musicales pendant la balance, doivent s'assurer que l'image audio soit correctement reproduite au sein de l'environnement matériel du concert. Dans cette optique, le choix du système de sonorisation, son positionnement dans la salle et ses réglages sont des étapes cruciales qui se déroulent sous la responsabilité des intermédiaires form in which music will be perceived by audiences. One recurring example was how a label, the manager, or another cultural intermediary would allot a technician of their own, who did not know the musicians before but eventually engages in a more or less long-term collaboration.

We showed that the construction of the audio image of musicians on stage largely depends on the type of relationship they have with technicians, and on the level of communication between them. Physical properties of sound and gear characteristics are marginally influential in performing this task. However, getting behind the mixing desk and mixing is only a part of technical work in live music. Before that, among other things, the PA system needs to be selected, mounted, and tuned to the acoustic environment in which it will play. Due to the object-related nature of this task, we can reasonably expect that this part of the job will be more driven by objects, environments, and tools.

\section{Non Relational Technical Mediation: Producing Homogeneous Sound throughout the Room}

Audio images may be conceived in rehearsals or in studios, far from the actual place in which they will be played. Thus, besides balancing the different music sources during the soundcheck, technical intermediaries of a live performance have to ensure that the audio image can be properly reproduced in the material environment of the concert. For this, the choice of the PA system, its position in the venue, and its adjustment are crucial elements that happen under the responsibility of technical intermediaries. The question that we need to ask here is to what extent these choices 
techniques. La question qu'il nous faut poser est celle de savoir à quel point ces choix sont le fruit de propriétés physiques d'environnements matériels, ou de paramètres interpersonnels du

monde de l'art.

Tout d'abord, remarquons que la console de mixage est un outil qui permet, avec certaines limites, de compenser les changements dus à l'environnement. Par exemple, dans le cas d'un groupe en tournée, si la salle du jour résonne à $2,5 \mathrm{kHz}$, ce qui n'était pas le cas de celle de la veille, cette fréquence peut être réduite via la console de mixage. Mais le mixage peut ne pas s'avérer suffisant pour répondre aux défis posés par un environnement acoustique. De fait, les environnements acoustiques peuvent déformer le travail de l'ingénieur du son et empêcher la production de l'image audio recherchée :

"Le problème, c'est qu'on jouait ce projet-là dans des lieux qui n'étaient pas du tout adaptés. C'était un projet ultra rock. Mais ultra rock, très très fort. Ultra rock'n'roll. Et on le jouait dans des endroits, genre, des salles de théâtre... on l'a fait à x [une salle de classique]. Dans une salle de classique, il y a quatre secondes de reverb. [...] J'ai dit "c'est hors de question, je ne ferai pas la face. Ça va être de la boucherie chevaline. C'est hors de question." Je lui dis "moi, si tu veux que je fasse les retours, je viens te faire les retours, c'est cool', par contre, faire du rock'n'roll dans cette salle avec quatre secondes de reverb, c'est du suicide. Ça ne va pas bien sonner devant, c'est l'enfer, et je ne veux pas faire ça. » (J, entretien.)

Dans cet exemple, il existait une contradiction entre les idées projetées par les producteurs et les contraintes matérielles nécessaires à leur mise en place. Celle-ci peut être compensée par une utilisation adéquate de la technologie du système are guided by physical properties of material environments, or by interpersonal characteristics of the art world.

First, we note that the mixing desk is a tool that can compensate, to a certain extent, for the changes in the environment. For instance, in the case of a band on tour, if today's room resonates at $2.5 \mathrm{kHz}$ and that was not the case in yesterday's room, the frequency can be reduced with the help of the mixing desk. But mixing may not be enough to address the challenges posed by an acoustic environment. Indeed, acoustic environments can distort the work of the sound engineer and impeach the production of the desired audio image:

"The problem is that we were playing this project in places that were not at all suitable. That was a very rock project, very loud. Ultra rock'n'roll. And we were playing it in like, theater venues... we did it in $\mathrm{x}$ [a classical music venue]. There's four seconds of reverb. [...] I said 'I won't do the front of house. It will be horse butchery, that's out of question.' I said: 'If you want me to do the monitor, l'll do the monitor, that's cool.' But doing rock'n'roll in a venue with four seconds of reverb, it's suicide. It will not sound good in front, that'll be hellish, and I don't want to do that." (J, interview.)

In this example, there was a gap between the ideas projected by producers and the material constraints of their project's implementation. This gap can be closed by an adequate use of the PA system technology. The general purpose of the sound 
d'amplification. L'objectif général du dispositif de reproduction sonore est d'offrir un son homogène pour tout le public, de proposer la même image audio à tous les spectateurs dans la salle. C'est un idéal impossible à atteindre en pratique, un cas typique de ce « point où un système de production se confronte à la réalité capricieuse du monde matériel » (Barley, 1996). La conception du système de sonorisation représente un moyen de s'approcher de cet idéal. Dans les années 1990, la technologie des Line Array a été introduite, entraînant un changement substantiel dans l'amplification des concerts. Plutôt que de concentrer la diffusion sonore sur un point qui couvre tout le public, le Line Array multiplie les sources afin que chacune se consacre à une partie du public reproducing device is to produce a homogeneous sound for the whole audience, to bring the same audio image of the music to everyone in the room. This is an ideal impossible to reach in practice, a typical case of the "point in which a production system meets the vagaries of the material world" (Barley 1996). The design of the PA system itself is a way to get closer to this ideal. In the 1990's, the technology of Line Array was introduced, leading to a substantial change in the concert amplification. Rather than concentrating the sound diffusion in one point that targets the whole audience, the Line Array multiplies the sources so that each is focused on one part of the audience only. seulement.

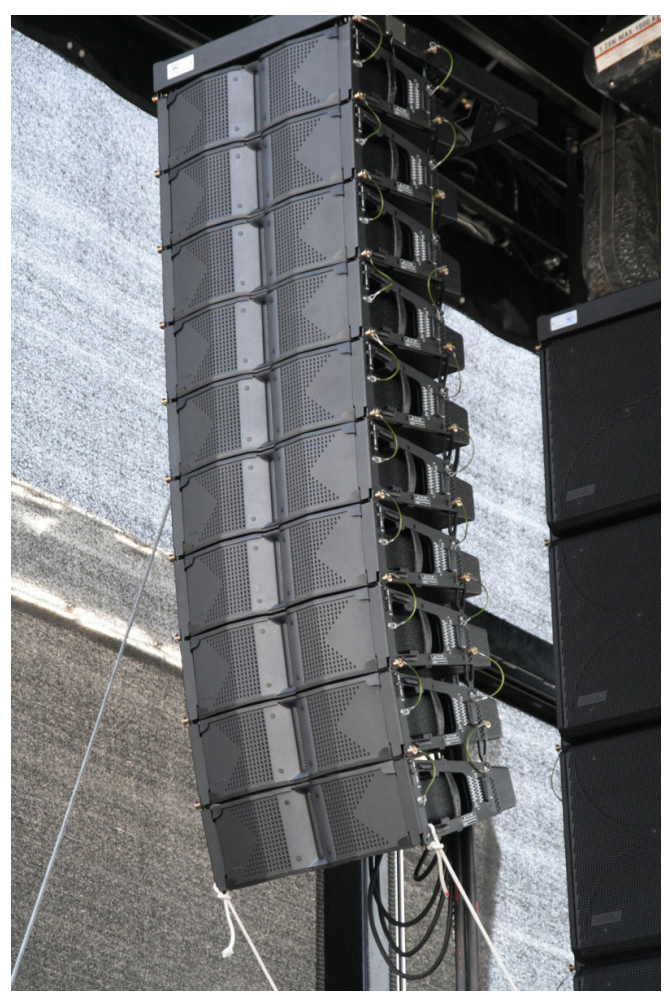

Fig. 3. Exemple d'un système Line Array / Example of a Line Array system Source : Wikipedia, par Rudolf Schuba. 
Le son qui parvient aux oreilles du public est moins réverbéré, et par conséquent moins distordu, grâce à la perception du son plus clair qui sort directement des haut-parleurs et qui se trouve sous le contrôle de l'ingénieur du son de façade :

« C'est notre but, en tant qu'ingénieurs système, d'installer des enceintes qui vont arroser... enfin, qui ne vont être dirigées que vers le public, là où il y a du public. Le but, c'est de ne focaliser vraiment que là où il y a du public pour éviter d'aller disperser du son et créer des problèmes.
Ouais.
$\mathrm{Si}$
t'arroses
les
murs...

- Voilà, t'as de la réverbération, ça vient brouiller le son direct et tout. » (C, entretien.)

La tâche d'accorder le système de sonorisation au lieu est présente dans toutes nos observations. Le système doit être assemblé de $A$ à Z, par exemple pour des festivals ou pour d'autres événements éphémères de la sorte. II est installé de façon permanente dans les lieux qui accueillent régulièrement des concerts. Cependant, le système est toujours " calibré », ce qui signifie que l'ingénieur du son façade s'assure que le système ne provoque aucune distorsion en lui-même. II ressort de nos observations que l'ingénieur du son s'acquitte souvent de cette tâche en jouant un morceau de musique qu'il connaît bien et en comparant ce qu'il entend avec ce qu'il attend de ce morceau. Mais on peut également avoir recours à la technologie, plus particulièrement dans les grosses productions. Au cours de deux observations, nous avons pu remarquer l'utilisation d'un « balayage sinusoïdal ». Un microphone de mesure est placé dans la salle et un son sinusoïdal est joué sur tout le spectre de fréquences audio.
Less reverberated, and thus distorted, sound reaches the audience's ears, to the benefit of the perception of the much clearer sound that comes directly out of the speakers, and that is under control of the front of house engineer:

"Our goal as system engineers, is to install speakers that will spray... well that will be directed to the audience, where there is audience. The purpose is to really only focus where there's an audience to avoid sound dispersion, that will create problems... - Yeah, if you spray the walls... - Exactly, you've got reverberation. It blurs the direct sound and all." (C, interview.)

This task of tuning the PA system is a constant in all our observations. The system may need to be mounted, for instance in festivals or other such ephemeral events. It is permanently installed in venues that perform concerts regularly. However, the system is always "calibrated," meaning that the front of house engineer ensures that there is no distortion provoked by the system itself. In our observations, it was generally done by playing a piece of music that the engineer knew well, comparing what was heard from what was expected for the tune to sound good. But technology can also be used, especially in big productions. In two observations, we have seen the use of a "sine sweep." A measure microphone is placed in the room, and a sinusoidal sound is played at all ranges of frequencies. 


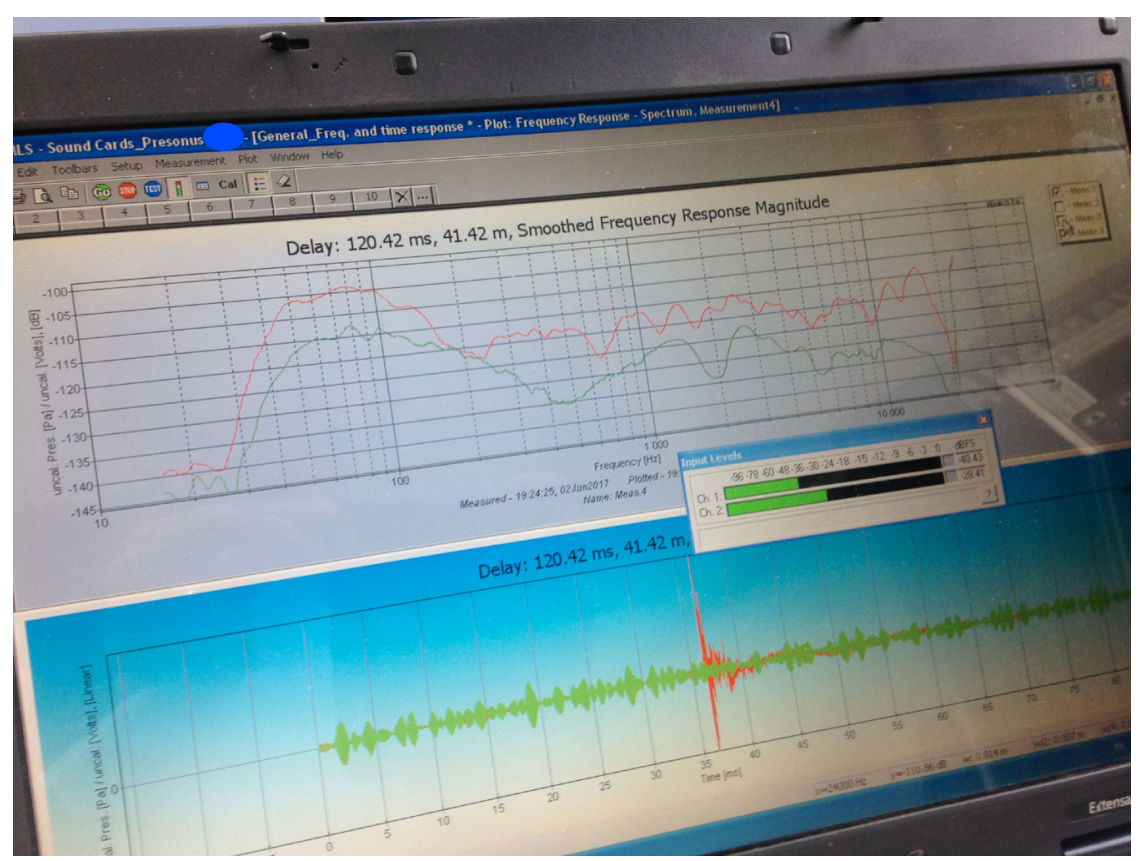

Fig. 4. Réponse en fréquence à un balayage sinusoïdal / Response in frequencies to a sine sweep (c) Photo de terrain par Andy Battentier / field photo by Andy Battentier.

Le graphique qui en résulte (voir Figure 4) est analysé et le calibrage du système est modifiée en fonction de ce qu'il montre. L'ingénieur du son reste toutefois celui qui prend la décision en dernière analyse :

" Le juge final, c'est toujours tes oreilles...T'as beau avoir tous les analyseurs que tu veux, c'est à l'oreille, moi, que je finis de calibrer un système. Et... tout a l'air beau sur l'analyseur, et puis finalement de la merde complète, là. [...] 2,3 \% du temps là que tu vois, t'as vraiment un... t'as des systèmes qui réagissent, c'est vraiment bizarre, des systèmes qui réagissent pas pareil. Ils vont donner
The graph that results is analyzed and the system calibration is modified in function of what is displayed. However, the sound engineer stays the final decision-taker:

"The final judge is always your ears... You can have all the analyzers you want, I use my ears to finish calibrating a system...Everything may look good on the analyzer, and then you have complete shit coming out. [...] 2,3\% of the time, you have systems that react... that's really weird, you have systems that don't react as usual. They will give you a flat response and the analyzer, you have a sweet 
le même tracé plat sur l'analyseur, t'as une belle réponse en fréquence plate, mais à l'oreille on dirait que certains systèmes te donnent plus de hautes fréquences, bien que la mesure empirique te dise que c'est exactement pareil [...]. II y a comme une... une quatrième composante, pas sur nos analyseurs, ou une troisième composante plutôt. Je ne sais pas exactement ce que c'est, là, mais ça vaut toujours la peine d'écouter pour s'assurer que ça ne soit pas en train de te nuire. » $(R$, entretien.)

La personne citée ici travaille au plus haut niveau, pour des concerts internationaux où l'on utilise les technologies les plus avancées au monde. Dans ce cas, la technologie permet d'assister le jugement d'un professionnel aguerri et expérimenté. Pour comprendre ce qui peut permettre de rétrécir le fossé entre l'idée d'un concert et sa mise en œuvre matérielle, nous pouvons voir que l'influence de la formation et de l'expérience des intermédiaires techniques prévaut sur les choix technologiques dans les processus pratiques, quel que soit le type de technologie utilisé. Toutefois, avant de pouvoir compter sur de telles technologies, encore faut-il en avoir le besoin et être capable de les financer. Dans les grands concerts, il est impossible pour un seul être humain de gérer à la fois le mixage et l'assemblage du système de sonorisation. Dans ce cas, un spécialiste de montage peut être embauché, si cela est financièrement envisageable.

« Je m'occupe du système de diffusion pour le public [...]. En fait, ça c'est dans les grosses tournées. T'as un technicien, un ingénieur système qui gère le système de diffusion. » (C., entretien.)

Ainsi l'accordage des systèmes de sonorisation aux conditions matérielles dépend de deux facteurs. Premièrement, il est dépendant des moyens des producteurs, qui permettent de response in flat frequency, but with your ears it sounds like some systems give you more high frequencies, despite the empirical measure [...]. There's something like, a third factor, not on our analyzers. I don't know exactly what this is, but it's always worth listening to ensure that it's not ruining everything." (R, interview.)

The person quoted here works at the highest level of international concerts, where the most advanced technology available worldwide is used. In this case, technology works to assist the subjective feeling of a trained and experienced professional. If we are trying to understand what can close the gap between the projected show and its material implementation, we can see that the influence of education and experience of technical intermediaries prevails on technological choices in practical processes, whatever the range of technologies used. However, before relying on such technologies, one has to need it, and to be able to fund it. In big shows, handling both the tasks of mixing, and mounting the PA system is too complex for a single human being. In this case a specialist of the mounting can be appointed, if this is financially feasible:

"I am dealing with the diffusion system for the audience. [...] That's for big tours. You have a technician, a system engineer who handles the diffusion system." (C, interview.)

Hence, proper attunement of PA systems to material conditions relies on two factors. First, it relies on the means available to producers, that give the possibility to acquire technologies and the 
faire l'acquisition de technologies et de recruter les personnes qualifiées pour les manipuler. Deuxièmement, cet accordage dépend des systèmes de formation suivis par les intermédiaires techniques, qu'il s'agisse de formation scolaire ou d'expérience professionnelle. Ces systèmes permettent de forger les aptitudes à utiliser adéquatement ces technologies, c'est-à-dire à la fois de savoir exploiter le potentiel de ces dispositifs et de savoir faire preuve de créativité lorsqu'on est confronté à un problème concret. En outre, ces systèmes de formation donnent aux techniciens la possibilité de connaître les limites du matériel qu'ils utilisent. Nous avons pu observer l'importance de ce savoir théorique, pratique et empirique dans le cadre d'un festival organisé dans une église. La programmation faisait la part belle à des concerts de pop amplifiée et de musique électro. La réverbération de dix secondes de l'église était impossible à ignorer. C'est pourquoi, dans l'optique d'offrir un son précis, l'ingénieur du son, une personne d'une trentaine d'année ayant bénéficié de l'un des meilleurs programmes de formation des ingénieurs du son en France, a dû placer des hautparleurs de rappel selon un plan précis :

" Le problème, ici, c'est que le son réverbéré va rapidement passer par-dessus le son direct, qui sort de l'enceinte. En gros, à dix mètres, t'es mort. T'entends plus la réverb que le son de l'enceinte et tu ne comprends rien. Du coup, l'idée, c'est de mettre un rappel à dix mètres de la scène, un autre cinq mètres plus loin, et encore un autre, etc. Comme ça, tout le monde est couvert directement par un haut-parleur. » (Ingénieur du son, conversation informelle pendant l'observation.)

Toutefois, il a clairement expliqué qu'il ne « luttait » pas contre la réverbération du lieu, ce qui aurait produit un son « terne ». II a plutôt intégré celle-ci dans son mix. II n'était certes pas capable de la contrôler avec un fader, mais plus indirectement par le biais people able to handle it. Second, it relies on educational systems training technical intermediaries, whether through education or professional experience. These systems develop the abilities to properly use technologies, both in terms of exploitation of their potential and of emergence of creative uses in front of concrete problems. Moreover, they also inform technicians of the limitations of the gear they are using. We have witnessed the importance of this theoretical, practical and empirical knowledge in a festival organized in a church. The programming included a good share of amplified pop and electro music. The ten seconds reverb of the church was quite impossible to ignore. Hence, in order to provide a clear sound, the sound engineer, a person in his 30s who benefited from one of the most advanced education program in sound engineering in France, had to place recall speakers with a precise pattern:

"In this place, the problem is that the reverberated sound will quickly overcome the direct sound you hear from the speaker. Ten meters from it and you're done, basically. You hear more reverberation than the sound of the speaker and you don't get a thing. So the idea is to put a recall [rappel] speaker at ten meters from the stage, and another one five meters further, and another one, etc., in this way everyone is always covered by a speaker." (Sound technician, small talk on the spot during observation.)

However, he explicitly said that he was not "fighting" the reverberation of the place, as it would have resulted in a "dull" sound. He rather integrated it into his mix, as a part that he was not able to directly control with a fader, but rather indirectly through other methods. 
d'autres stratagèmes. Cet usage subtil de la technologie permettant d'appréhender un environnement acoustique plutôt hostile à un concert pop, c'est à sa formation qu'il le doit. Et cette méthode pouvait être mise en œuvre avec du matériel basique. Une autre observation, qui se déroulait dans une salle semi-cylindrique de vingt mètres de haut, posait le même problème de réverbération, avec les mêmes enceintes. Mais aucun des ingénieurs présents n'a eu l'idée ou la possibilité de répartir les haut-parleurs dans la salle. Par conséquent, le mixeur n'a pas été en mesure de produire

le son voulu.

Le travail des intermédiaires techniques apparaît ici comme la réponse aux contradictions inhérentes posées par la concrétisation matérielle des plans d'un projet. Les problèmes surviennent lorsque l'environnement s'oppose aux intentions des producteurs. $\mathrm{Si}$ les propriétés matérielles de l'environnement sont de fait examinées pendant le calibrage, la capacité à les affronter dépend des moyens matériels et humains disponibles pour la mise en œuvre de la dimension matérielle du projet. Économiquement, il faut de l'argent pour payer les travailleurs et le matériel. Du point de vue pratique, les travailleurs doivent être en capacité d'exploiter pleinement le potentiel des technologies. Cette aptitude dépend de la qualité de leur formation, qu'il s'agisse d'éducation primaire ou de transmission professionnelle, mais aussi d'une bonne répartition de la responsabilité. Le tableau nous apparaît ainsi bien plus complexe qu'un simple dialogue entre l'humain et la matière dans lequel la seconde déterminerait l'issue d'une situation.
This subtle use of technology in order to apprehend an acoustic environment rather hostile to a pop concert was allowed by his training, and only required casual gear to be implemented. Another observation, happening in a semi-cylindric hall of twenty meters height, had the same reverberation problem and the same kind of speakers, but none of the engineers came up with the solution of spreading speakers across the room. As a result, the mixer did not manage to produce the intended sound.

Here, the work of technical intermediaries appears as the answer to the contradictions inherent in the materialization of a project's design. Problems appear when the environment constrains the producers'intentions. While material properties of the environment are indeed considered during calibration, the ability to cope with them depends on the material and human means available to materially implement the project. Economically, money is needed to pay for workers and materials. Practically, workers must be able to fully exploit the potential of technologies. This ability depends on the quality of their training, whether through primary education or professional transmission, coupled with an accurate distribution of responsibility. The picture, then, appears to be much more complex than a dialogue between humans and materials, in which the latter heavily determines how the situation issues. 


\section{Contraintes matérielles et conventions : l'aptitude technique comme terrain de l'agentivité dans la relation entre personnes et choses}

L'étude des pratiques professionnelles des intermédiaires techniques au sein de deux tâches essentielles à la production d'un concert a permis de distinguer les influences matérielles et relationnelles sur le travail technique. Notre analyse montre que le travail des intermédiaires techniques répond surtout à des facteurs relationnels au cours d'un concert de musique live. L'environnement matériel ne fait que répondre aux plans conçus par les personnes du monde de l'art.

Dans un monde de l'art, les conventions sont les piliers d'une performance réussie : elles permettent aux musiciens, aux techniciens, aux intermédiaires culturels et au public de trouver des significations communes à l'événement auquel ils participent - les concerts dans le cas étudié. Les intermédiaires culturels produisent un cadre symbolique pour le travail des musiciens, permettant ainsi de le relayer à un public sous une forme qui ait du sens, tant d'un point de vue économique que symbolique. Ils se servent de références culturelles et de compétences sociales pour mobiliser des canaux de distribution afin de créer une connexion réussie entre les artistes et le public (Becker 1982 ; Lizé 2016 ; Maguire \& Matthews 2012 ; Negus 2002). Cette organisation constitue en soi un système productif, au sens où l'entend Stephen Barley (1996). Les conventions de ce système culturel se trouvent à un point médian entre les visions esthétiques des artistes, les besoins des intermédiaires culturels et les goûts du public. Mais les conventions sont relativement indépendantes des propriétés matérielles de l'environnement dans lequel s'ancre un concert. Les conventions se structurent davantage par le biais d'un processus qui préexiste au concert. Même s'il peut dépendre à un moment

\section{Material Constraints and Conventions: Technical Ability as the Locus of Agency in the Relation between People and Things}

Through the study of the working practices of technical intermediaries on two central tasks leading to a concert production, we have been able to disentangle material and relational influences on technical work. This analysis shows that the work of technical intermediaries is mostly driven by relational factors during a live music performance. The material environment is providing a response to the intentions driven by people of the art world.

In an art world, conventions are the cornerstones of a successful performance: they allow musicians, technicians, cultural intermediaries and audiences to find common meaning in the event in which they are participating-concerts in the cases that we studied. Cultural intermediaries produce a symbolic frame for the musicians' work, thus relaying it to an audience in a form that makes both economic and symbolic sense. They use cultural references and social skill to mobilize distribution canals in order to organize a successful connection between artists and audiences (Becker 1982; Lizé 2016; Maguire \& Matthews 2012; Negus 2002). This organization is in itself a production system, in the sense of Stephen Barley (1996). Conventions of this cultural system constitute a middle point between the artist's aesthetic views, the cultural intermediaries' needs and the audience's tastebuds. But conventions are relatively independent from material properties of the environment in which a performance takes place. Instead, conventions are constructed through a process happening before the actual concert. Although it might be at some point rely on material elements, this process goes far beyond the material conditions in which the concert actually happens. Commercial practices (Becker 
d'éléments matériels, ce processus va bien au-delà des conditions matérielles d'exécution du concert. Les pratiques commerciales (Becker 2010), les relations de pouvoir (Becker 2010) et les pratiques culturelles (Becker 2010) sont quelques exemples de ce processus de plus grande ampleur que Howard Becker considère comme essentiel pour expliquer l'adoption d'une convention par un monde de l'art.

D'un autre côté, les contraintes matérielles sont toujours liées à un temps et à un espace. Chaque lieu sonne différemment, chaque système de sonorisation possède ses caractéristiques propres, chaque microphone a sa manière de transformer le son. En outre, un même lieu ne sonnera pas de façon identique à des moments différents, les changements météorologiques (en particulier le taux d'humidité), la présence ou la taille du public ayant une influence sur la propagation du son dans l'air.

Le rôle des intermédiaires techniques consiste précisément à modeler à la fois les propriétés matérielles de l'environnement et celles de la musique pour que les conventions puissent s'appliquer indépendamment de l'environnement. Les techniciens que nous avons étudiés ont un objectif : reconstruire une image audio du groupe sur scène, en fonction du consensus établi par d'autres acteurs du monde de l'art, qui se forme et qui s'exprime par des conventions artistiques. Afin d'atteindre cet objectif, les techniciens doivent prendre en compte les propriétés matérielles de l'environnement dans lequel l'image est construite, et ils utilisent des outils qu'ils sont les seuls à maîtriser au sein de leur environnement professionnel. En d'autres termes, les attentes quant à la nature de l'image audio sont définies indépendamment du lieu où se tient le concert, et les techniciens doivent les prendre en compte afin de fournir une image qui réponde à ces attentes. Ils utilisent à cette fin des outils spécifiques, ce qui peut nous faire
1982: 46), power relationships (Becker 1982: 47), and cultural practices (Becker 1982: 48), are some examples of the larger processes Howard Becker mentions as crucial for explaining the adoption of a convention by an art world.

Material constraints, on the other hand, are always attached to a particular time and place. Each room sounds differently, each PA system has its own characteristics, each microphone transforms the sound in its own way. Moreover, the same place will not sound the same at two different moments in time, as changes in the weather and particularly the humidity rate, or the presence and size of the audience, will transform the way sound propagates through air.

The role of technical intermediaries is precisely to shape material properties of both the environment and the music in order for conventions to be applied independently of the environment. The technicians we studied have an objective: to rebuild an audio image of the band on stage, defined by the consensus reached beforehand by other actors involved in the art world, which is shaped by and expressed through artistic conventions. In order to achieve their objective, technicians have to account for the material properties of the environment in which this image is built, and they rely on specific tools that they are the only one to master in their working environment. In other words, the expectations of the shape of the audio image are defined independently of the environment in which the concert will take place, and technicians will have to deal with them in order to provide an image that fits these expectations. As they are using specific tools for this purpose, we can consider 
considérer qu'ils prennent part à une forme d'association entre entités humaines et non humaines au sens de la théorie de l'acteurréseau (Callon 1986)

Cependant, nos observations tendent à remettre en cause l'idée de symétrie généralisée qui se trouve au cœur de cette théorie. En effet, il est clair que la fonction des ingénieurs du son est précisément d'éliminer autant que possible les effets de la variabilité matérielle afin que les aspects de l'image audio déterminés comme essentiels par les conventions ne subissent pas de modifications. Pour les ingénieurs du son, les environnements sont un ensemble de paramètres qu'ils devront prendre en compte pour remplir un objectif déterminé indépendamment de ces environnements. Pour cela, ils élaborent une stratégie en se fondant sur leur formation et leur expérience, par exemple l'intégration ou la suppression d'un son réverbéré dans l'image audio. Ainsi, ce ne sont clairement pas les objets et les environnements qui prennent eux-mêmes des décisions, ou qui élaborent des stratégies pour contrer les plans des ingénieurs du son. En ce sens, les environnements, les outils et les personnes ne peuvent être considérés comme des participants égaux à un réseau. La « négociation » d'actants non humains résulte dans ce cas du travail de cadrage des intermédiaires techniques qui intègrent les éléments matériels au réseau. Postuler une symétrie généralisée rend ce travail invisible à l'analyse et finit par surestimer l'influence des objets.

C'est pourquoi nous proposons, plutôt que d'agentivité matérielle, de parler d'aptitude technique. L'aptitude technique désigne dans notre contexte la capacité des intermédiaires techniques à matérialiser les objets culturels selon les conventions, et correspond à la faculté humaine d'analyser et d'anticiper les réactions physiques des objets et des environnements. C'est ce qui va déterminer la réponse humaine à la façon dont la matière va that it constitutes a form of association between humans and nonhuman entities, in the sense of actor network theory (Callon 1984).

But our observations call into question the notion of generalized symmetry at the core of this theory. Indeed, it is clear that the function of sound engineers is precisely to cancel, as much as possible, the effects of material variability, so that essential conventionally meaningful aspects of the audio image are not modified. Environments are a given parameter to them, around which they will have to work to achieve a purpose defined independently of these environments. For that, they will implement a strategy on the basis of their education and experience, for instance through the integration or suppression of reverberated sound in the audio image. Clearly, therefore, objects and environments do not take decisions by themselves, and will not purposefully implement a strategy to counter the sound engineers' plan. In this sense, environments, tools, and people cannot be considered as equal participants in a network. The "negotiation" of non-human actants results in this case from the framing work of technical intermediaries that integrate the material in the network. Assuming generalized symmetry erases this work from the analysis, and thus overestimates the influence of objects.

This is why we propose, instead of speaking of material agency, to rather talk about technical ability. Technical ability, that is in our case the ability of technical intermediaries to materialize cultural objects according to conventions, is the human ability to address and manage objects' and environments' physical reactions. It is what determines the human response to the reaction that materials will produce in response to human intention. Technical 
réagir à l'intention humaine. L'aptitude technique définit la capacité à adapter ses moyens d'action aux défis posés par un contexte spécifique. Pour notre travail de terrain, cette aptitude repose sur la capacité des intermédiaires techniques à comprendre les objectifs d'autres acteurs (humains) du monde de l'art, par le biais de la communication, en puisant dans leurs connaissances et leur expérience des outils qu'ils utilisent pour mener cette mission à bien. Ces deux facultés sont le produit de la socialisation, un concept qui s'appuie à la fois sur les perspectives théoriques structurelles et interactionnelles.

Pour suivre une métaphore mathématique, l'agentivité humaine sur les objets et les environnements représente le résultat d'une équation à plusieurs variables : les ressources et compétences techniques, imaginatives et économiques. Cette équation doit bien évidemment inclure les propriétés de l'environnement matériel, mais en tant que constantes. Dans l'analyse du monde social, le monde matériel représente généralement plutôt une contrainte qu'une variable déterminante. Prendre en compte les propriétés physiques de l'environnement au même titre que les interactions interpersonnelles dans les sciences sociales est problématique, tant du point de vue théorique (Elder-Vass 2008, 2015) que pratique. Cela peut nous conduire à négliger l'agentivité humaine sur les contraintes matérielles, issue des organisations ou des institutions sociales inventées pour faire face aux défis collectifs. Ainsi, cela peut nous amener à surestimer l'influence des objets et environnements, mais, pire encore, à sous-estimer l'aptitude humaine à faire face aux défis posés par ceux-ci. Pour finir, cela peut nous amener à oublier les raisons et les intentions qui se cachent derrière toute action sur le monde matériel, celles-ci étant relativement indépendantes des lois de la physique. La technologie, si elle est en effet associée aux humains et au monde matériel, reste essentiellement un outil qui sert des objectifs et que l'on doit ability defines the capacity to successfully adapt the means to the challenge posed by a specific context. In our fieldwork, the ability to do so relies on technical intermediaries' capacity to understand the purposes of other (human) actors of the art world through communication, and on their knowledge and experience of the tools they are using to materially achieve these purposes. Both capacities are constructed by socialization, a concept that relies both on structural and interactional theoretical perspectives.

To use a mathematical metaphor, human agency on objects and environments is thus the result of an equation in which the variables are technical, imaginative, and economic resources and abilities. In this equation, properties of the material environment must of course be included, but as a constant. In social analysis, the material world typically is a constraint rather than a determining variable. Accounting for physical properties of the environment in the same way as interpersonal interactions in social sciences, is problematic theoretically (Elder-Vass 2008,2015 ) and practically. It can lead us to overlook human agency over material constraints, built through the social organizations or institutions invented to face collective challenges. Therefore, it can lead to an overestimation of the material's impact, and worse, to underestimation of human ability to face material challenges. Finally, it can lead us to forget that behind any action intended on the material there are intentions and purposes that are socially constructed, and relatively independent of any physical law. Technology, if it is indeed associated with humans and the material, is essentially a tool that serves these purposes and that needs to be adapted to it. In a professional context, such as a concert production, this task is the one of technical intermediaries. Therefore, "material agency" depends 
adapter à ceux-ci. Dans un contexte professionnel comme celui de la production de concert, ce sont les intermédiaires techniques qui se chargent de cette tâche. Ainsi, " l'agentivité du monde matériel » dépend davantage du travail et des médiations que ces derniers produisent que des propriétés physiques des matériaux.

\section{Conclusion : la musique comme signification} et comme technologie

Cet article s'est consacré à l'analyse des pratiques professionnelles des ingénieurs du son de musique live, une catégorie spécifique d'intermédiaires techniques. En interrogeant le concept de « personnel de renfort » (Becker 2010), nous avons dressé un tableau des mondes de l'art constitué de quatre types d'acteurs: les artistes, le public, les intermédiaires techniques et les intermédiaires culturels. Nous avons montré le rôle spécifique joué par les intermédiaires techniques, qui consiste schématiquement à modifier la forme physique des objets culturels afin de les faire correspondre aux attentes conventionnelles de leur monde de l'art. En outre, notre analyse a interrogé la "symétrie généralisée » postulée par la théorie de l'acteur-réseau (Callon 1986), en montrant que "l'agentivité des objets » se laissait mieux saisir par la notion « d'aptitude technique », c'est-à-dire par la capacité à mobiliser des ressources sociales, économiques et culturelles pour faire face à des défis matériels. Nous avons affirmé le rôle constitutif au sein de l'aptitude technique des moyens économiques et sociaux des acteurs du monde de l'art, du niveau d'éducation et d'expérience des intermédiaires techniques, du type de relation et de la qualité de communication entre artistes et techniciens. Les propriétés physiques des objets et de l'environnement, ou les technologies disponibles, ont un rôle mineur dans la définition de

l'aptitude technique. more on their work and the mediation that they produce rather than on the material physical properties.

\section{Conclusion: Music as Meaning, and Technology}

This article analyzed the working practices of live music sound engineers, a particular category of technical intermediaries. By questioning the notion of "support personnel" (Becker 1982), we presented a picture of art worlds as constituted of four kinds of actors: artists, audiences, technical and cultural intermediaries. We showed the specific role of technical intermediaries, which broadly consists in modifying the physical shape of cultural objects in order to make them correspond to the conventional expectations of their art world. Furthermore, our analysis questioned the "generalized symmetry" postulated by ANT (Callon 1984), and showed that "the agency of objects" was more accurately seized by the notion of "technical ability," i.e. the capacity to mobilize social, economic and cultural resources to face material challenges. We identified the economic and social means of actors of the art world, the education and experience level of technical intermediaries, the types of relation and quality of communication between artists and technicians as primarily influencing technical ability, against physical properties of objects and environment, or available technologies. 
Ces conclusions ont des implications plus larges pour notre compréhension de la production de la culture, ainsi que de

l'agentivité et du rôle social des objets.

Tout d'abord, nous avons démontré que la notion beckerienne de «personnel de renfort » ne permettait pas de saisir de façon adéquate le travail technique dans les mondes de l'art. En effet, nous avons vu que les intermédiaires techniques font bien plus que de remplir des missions que les artistes ou d'autres membres des mondes de l'art pourraient effectuer, mais préfèrent déléguer par manque de temps ou d'intérêt : leur contribution est cruciale, à la fois pendant le processus de création, et au cours de son exécution. Ils apportent une compétence spécifique vis-à-vis de la technologie, qui est nécessaire à la réalisation de l'activité culturelle, et ils se servent de cette compétence pour faire des choix autonomes et créatifs qui influencent la forme finale de l'objet culturel.

Les intermédiaires techniques sont présents dans l'intégralité de la production culturelle, partout où celle-ci suppose de modifier le contenu artistique afin de le faire entrer dans le cadre conçu par les intermédiaires culturels pour sa présentation à un public. La typologie des mondes de l'art que nous proposons ici n'a pas pour but d'enfermer les acteurs dans des rôles figés. Elle aspire plutôt à décrire les différentes actions nécessaires à la production d'un objet ou d'une interprétation culturelle chargée de signification. Nous proposons un cadre précis d'analyse comparative de la distribution de tâches, des pouvoirs et des responsabilités dans les différents mondes de l'art. Les intermédiaires techniques offrent une porte d'entrée intéressante pour comprendre les attentes des autres acteurs. Situés à la dernière étape du procédé de production, leur travail réunit toutes les tentatives des différents acteurs de modifier l'objet culturel, ce qui permet de les rendre facilement observables pour le chercheur. Cette position se retrouve par ailleurs dans
These results have a number of wider implications for our understanding of cultural production, and the agency and social role of objects.

First, we showed that Howard Becker's notion of "support personnel" does not adequately capture technical work in art worlds. Indeed, we saw that more than simply delegating tasks that artists or other members of the art world could do themselves but do not have the time or interest in, technical intermediaries provide crucial input during a creative process, as well as during its performance. They bring a specific competence regarding technology that is necessary to perform the cultural activity, and they use this competence to make autonomous and eventually creative choices that impacts the final shape of the cultural object.

Technical intermediaries are present everywhere in cultural production, everywhere where artistic content must be modified in order to fit the frame designed by cultural intermediaries for a presentation to an audience. The typology of art worlds that we propose here does not intend to lock actors in specific and rigid roles. It rather aspires to describe the different actions necessary to issue a cultural object or performance charged with meaning. Hence, it provides a frame that will help us to comparatively study the distribution of tasks, power and responsibilities in different art worlds. In this frame, technical intermediaries provide a good entry point to understand other actors' expectations. Positioned at the last step of the production process, their work combines all the attempts from different actors to shape the cultural object in the way they think it should be according to their own position, making them easily observable by the researcher. This position, however, can eventually be found in other fields than the cultural one, fields 
d'autres champs que la culture où l'on retrouve un processus de transformation des conceptions vers des objets matériels.

Deuxièmement, notre critique de la symétrie généralisée nous a conduits à proposer le nouveau concept « d'aptitude technique ». Ce concept nous permet d'éviter l'anthropocentrisme au sein des sciences sociales, en permettant d'analyser l'agentivité et l'importance des objets sans pour autant tomber dans l'écueil du déterminisme matériel. II ouvre une perspective qui rend compte de l'influence des objets et des environnements, mais se concentre sur la façon dont la société s'organise pour les intégrer. Ainsi, ce concept invite à une exploration plus poussée : comment les processus sociaux peuvent-ils améliorer ou diminuer cette aptitude technique ? Comment les relations pré-existantes influencent-elles l'aptitude technique à un moment précis ? Quel rôle jouent les relations de pouvoir sur l'aptitude technique ? De telles questions nous tirent des interactions entre l'homme et la matière, pour nous amener vers des perspectives macroscopiques en sociologie pragmatique et critique. Ce changement radical de perspective peut amener un nouvel éclairage sur la façon dont les objets sont intégrés dans la vie sociale, et le rôle qu'ils jouent dans la construction de liens sociaux et de hiérarchies.

\section{Liste des personnes interrogées}

A : homme, début de trentaine, habitant en banlieue parisienne

$B$ : homme, fin de trentaine, habitant en banlieue parisienne

$\mathrm{C}$ : homme, début de quarantaine, habitant en banlieue parisienne

D : femme, milieu de trentaine, habitant à Tours

$\mathrm{E}:$ homme, milieu de quarantaine, habitant à Paris

$F$ : homme, fin de trentaine, habitant en région lyonnaise

$\mathrm{G}$ : homme, début de trentaine, habitant en banlieue parisienne where the process to transform designs in material objects is also found.

Second, our critique of generalized symmetry has led us to coin the new notion of "technical ability." This concept allows us to avoid anthropocentrism in social sciences, allowing us to understand the agency and importance of objects without falling in the pitfall of material determinism. It opens a perspective that accounts for the influence of objects and environments, but focuses on how society organizes itself in order to integrate them. Thus, the concept calls for further exploration: how is technical ability improved or diminished by social processes? How do previous interactions influence technical ability in a defined moment? How do power relationships influence technical ability? Such questions lead back the way from human-material interactions to macro-perspectives in pragmatic and critical sociology. As a radical change of perspective, it may shed a new light on how materials are integrated in social life, and what role they play in the construction of social bounds and hierarchies.

\section{List of respondents}

A: male, early 30 s, living in Paris suburbs

$\mathrm{B}$ : male, late 30 s, living in Paris suburbs

C: male, early 40s, living in Paris suburbs

D: female, mid 30s, living in Tours

$\mathrm{E}$ : male, mid-40s, living in Paris

$\mathrm{F}$ : male, late 30 s, living in Lyon's region

G: male, early 30 s, living in Paris suburbs

$\mathrm{H}$ : male, early 30 s, living in Paris

I: female, early 30s, living in Paris suburbs 
$\mathrm{H}$ : homme, début de trentaine, habitant à Paris

I : femme, début de trentaine, habitant en banlieue parisienne

$\mathrm{J}:$ homme, milieu de trentaine, habitant à Paris

$\mathrm{K}$ : homme, milieu de vingtaine, habitant à Paris

$\mathrm{L}$ : femme, milieu de trentaine, habitant à Paris

$M$ : homme, fin de vingtaine, habitant en banlieue parisienne

$\mathrm{N}$ : homme, milieu de trentaine, habitant à Paris

$\mathrm{O}$ : homme, début de trentaine, habitant en banlieue parisienne

$\mathrm{P}$ : homme, début de trentaine, habitant en banlieue parisienne

$\mathrm{Q}$ : homme, milieu de trentaine, habitant à Paris

$\mathrm{R}$ : homme, début de quarantaine, habitant à Montréal

$\mathrm{Z}$ : premier auteur pendant les interactions des entretiens

Andy Battentier

Università degli studi di Milano - Network for the Advancement of Social and Political Studies (NASP) ; University of Amsterdam - Amsterdam Institute for Social Science Research (AISSR)

Giselinde Kuipers

Université catholique de Louvain - Centre de recherche sociologique (Ceso)

\section{Références bibliographiques}

AKRICH Madeleine (1992). «The De-Scription of Technical Objects ». In BIJKER Wiebe \& LAW John (dir.), Shaping Technology/Building Society : Studies in Sociotechnical Change. Cambridge, The MIT Press.

AKRICH Madeleine (1993). «Les formes de la médiation technique ». Réseaux, 60 : 87-98.

AKRICH Madeleine (2010). «Comment décrire les objets techniques ?». Techniques \& culture, 9 .

AkRICH Madeleine, Callon Michel, Latour Bruno (dir.) (2006). Sociologie de la traduction. Textes fondateurs. Paris, Presses des Mines.
J: male, mid-30s, living in Paris

$\mathrm{K}$ : male, mid-20s, living in Paris

L: female, mid 30s, living in Paris

M: male, late 20s, living in Paris suburbs

$\mathrm{N}$ : male, mid 30s, living in Paris

O: male, early 30 s, living in Paris suburbs

$P$ : male, early 30 s, living in Paris suburbs

Q: male, mid 30s, living in Paris

R: male, early 40s, living in Montréal

$Z$ : first author during interviews interactions

Università degli studi di Milano - Network for the Advancement of Social and Political Studies (NASP) ; University of Amsterdam - Amsterdam Institute for Social Science Research (AISSR) Giselinde Kuipers

Université catholique de Louvain - $\underline{\text { Centre de recherche sociologique (Ceso) }}$

\section{References}

AKRICH Madeleine (1992). "The De-Scription of Technical Objects." In BIJKER Wiebe \& LAW John (eds.), Shaping Technology/Building Society : Studies in Sociotechnical Change. Cambridge, MIT Press.

AKRICH Madeleine (1993). "Les formes de la médiation technique." Réseaux, 60: 87-98.

AKRICH Madeleine (2010). "Comment décrire les objets techniques ?" Techniques \& culture, 9.

AKRICH Madeleine, CalLon Michel, Latour Bruno (eds.) (2006). Sociologie de la traduction. Textes fondateurs. Paris, Presses des Mines. 
BARLEY Stephen (1996). «Technicians in the Workplace : Ethnographic Evidence for Bringing Work into Organizational Studies ». Administrative Science Quarterly, 41(3).

BECKER Howard (2010) [1982]. Les Mondes de l'Art. Traduit de l'anglais par Jeanne Bouniort. Paris, Flammarion.

CALLON Michel (1986). «Eléments pour une sociologie de la traduction : la domestication des coquilles Saint-Jacques et des marins-pêcheurs dans la baie de Saint-Brieuc ». L'Année Sociologique, 36 : 169-208.

DeNora Tia (2000). Music in Everyday Life. Cambridge, Cambridge University Press.

Domínguez RuBIO Fernando (2012). «The Material Production of the Spiral Jetty : A Study of Culture in the Making ». Cultural Sociology, 6(2) : 143-161.

Domínguez RuBIO Fernando (2014). «Preserving the Unpreservable : Docile and Unruly Objects at MoMa ». Theory and Society, 43(6) : 617645.

Domínguez RuBIO Fernando (2016). « On the Discrepancy between Objects and Things : An Ecological Approach ». Journal of Material Culture, 21(1) : 59-86.

ElDER-VASS Dave (2008). «Searching for Realism, Structure and Agency in Actor Network Theory ». The British Journal of Sociology, 59(3) : 455473.

EldeR-VASS Dave (2015). «Disassembling Actor-Network Theory ». Philosophy of the Social Sciences, 45(1) : 100-121.

GomART Émilie \& HENNION Antoine (1999). «A Sociology of Attachment : Music Amateurs, Drug Users ». The Sociological Review, 47(1) : 220-247.

Griswold Wendy, Mangione Gemma, McDonnell Terence (2013). «Objects, Words, and Bodies in Space : Bringing Materiality into Cultural Analysis ». Qualitative Sociology, 36(4), 343-364.
BARLEY Stephen (1996). "Technicians in the Workplace: Ethnographic Evidence for Bringing Work into Organizational Studies." Administrative Science Quarterly, 41(3).

BECKER Howard (1982). Art Worlds. Berkeley, University of California Press.

CALLON Michel (1984). "Some Elements of a Sociology of Translation: Domestication of the Scallops and the Fishermen of St Brieuc's Bay." The Sociological Review, 32(1): 196-233.

DeNora Tia (2000). Music in Everyday Life. Cambridge, Cambridge University Press.

Domínguez Rubio Fernando (2012). "The Material Production of the Spiral Jetty: A Study of Culture in the Making." Cultural Sociology, 6(2): 143-161.

Domínguez RuBio Fernando (2014). "Preserving the Unpreservable: Docile and Unruly Objects at MoMa." Theory and Society, 43(6): 617-645.

DOMíNGUEZ RuBIo Fernando (2016). "On the Discrepancy between Objects and Things: An Ecological Approach." Journal of Material Culture, 21(1): 59-86.

EldeR-VASS Dave (2008). "Searching for Realism, Structure and Agency in Actor Network Theory." The British Journal of Sociology, 59(3): 455473.

EldER-VASS Dave (2015). "Disassembling Actor-Network Theory." Philosophy of the Social Sciences, 45(1): 100-121.

Gomart Émilie \& HENNION Antoine (1999). "A Sociology of Attachment: Music Amateurs, Drug Users." The Sociological Review, 47(1): 220-247.

Griswold Wendy, Mangione Gemma, McDonnell Terence (2013). "Objects, Words, and Bodies in Space: Bringing Materiality into Cultural Analysis." Qualitative Sociology, 36(4): 343-364.

HenNion Antoine (2015) [2007]. The Passion of Music. A Sociology of Mediation. Translated from French by Margaret Rigaud. Oxford, Routledge. 
HenNION Antoine (2007). La Passion musicale. Une sociologie de la médiation. Paris, Métailié.

Hesmondhalgh David (2006). « Bourdieu, the media and cultural production ». Media, Culture \& Society, 28(2) : 211-231.

HORNING Susan (2004). «Engineering the Performance : Recording Engineers, Tacit Knowledge and the Art of Controlling Sound ». Social Studies of Science, 34(5) : 703-731.

KeAly Edward (1979). «From Craft to Art : The Case of Sound Mixers and Popular Music ». Sociology of Work and Occupations, 6(1) : 3-29.

KLETT Joseph (2014). «Sound on Sound : Situating Interaction in Sonic Object Settings ». Sociological Theory, 32(2) : 147-161.

KUIPERS Giselinde (2015). « How National Institutions Mediate the Global : Screen Translation, Institutional Interdependencies, and the Production of National Difference in Four European Countries ». American Sociological Review, 80(5) : 985-1013.

Latour Bruno (2006). Changer de société. Refaire de la sociologie. Paris La Découverte.

LAW John (2009). « Actor Network Theory and Material Semiotics ». In TURnER Brian S. (dir.), The New Blackwell Companion to Social Theory. Oxford, Wiley-Blackwell : 141-158.

LE Guern Philippe (2004). «Mutations techniques et division du travail : le cas des monteurs sons ». Volume !, 3. En ligne, consulté le 12 septembre 2019.

LETTOW Susan (2017). «Turning the turn : New Materialism, Historical Materialism and Critical Theory ». Thesis Eleven, 140(1) : 106-121.

LEYSHON Andrew (2009). «The Software Slump ? Digital Music, the Democratisation of Technology, and the Decline of the Recording Studio Sector within the Musical Economy ». Environment and Planning $A$ 41(6) : 1309-1331
Hesmondhalgh David (2006). "Bourdieu, the Media and Cultural Production." Media, Culture \& Society, 28(2): 211-231.

HoRNING Susan (2004). "Engineering the Performance: Recording Engineers, Tacit Knowledge and the Art of Controlling Sound." Social Studies of Science, 34(5): 703-731.

KeAly Edward (1979). "From Craft to Art: The Case of Sound Mixers and Popular Music." Sociology of Work and Occupations, 6(1): 3-29.

KLETT Joseph (2014). "Sound on Sound: Situating Interaction in Sonic Object Settings." Sociological Theory, 32(2): 147-161.

KUIPERS Giselinde (2015). "How National Institutions Mediate the Global: Screen Translation, Institutional Interdependencies, and the Production of National Difference in Four European Countries." American Sociological Review, 80(5): 985-1013.

LATOUR Bruno (2005). Reassembling the Social: An Introduction to ActorNetwork-Theory. Oxford, Oxford Univiversity Press.

LAW John (2009). "Actor Network Theory and Material Semiotics." In TuRner Brian S. (ed.), The New Blackwell Companion to Social Theory. Oxford, Wiley-Blackwell: 141-158

LE GUERN Philippe (2004). "Mutations techniques et division du travail: Ie cas des monteurs son." Volume !, 3. Online, accessed on 12 september 2019

LeTtow Susan (2017). "Turning the turn: New Materialism, Historica Materialism and Critical Theory." Thesis Eleven, 140(1): 106-121.

LEYSHON Andrew (2009). "The Software Slump? Digital Music, the Democratisation of Technology, and the Decline of the Recording Studio Sector within the Musical Economy." Environment and Planning A, 41(6) 1309-1331.

LINGO Elizabeth \& O’MAHONY Siobhán (2010). "Nexus Work: Brokerage on Creative Projects." Administrative Science Quarterly, 55(1): 47-81. 
LINGO Elizabeth \& O'MAHONY Siobhán (2010). « Nexus Work : Brokerage on Creative Projects ». Administrative Science Quarterly, 55(1) : 47-81.

LIZÉ Wenceslas (2016). «Artistic Work Intermediaries as Value Producers. Agents, Managers, Tourneurs and the Acquisition of Symbolic Capital in Popular Music ». Poetics, 59 : 35-49.

MAGUIRE Jennifer \& MatTHEws Julian (2012). "Are We All Cultural Intermediaries Now ? An Introduction to Cultural Intermediaries in Context ». European Journal of Cultural Studies, 15(5) : 551-562.

Mercier Denis (dir.) (2017). Le Livre des techniques du son. Tome 2, La technologie. Paris, Dunod.

NEGUS Keith (2002). « The Work of Cultural Intermediaries and the Enduring Distance between Production and Consumption ». Cultura Studies, 16(4) : 501-515.

Perrenoud Marc (2007). Les Musicos. Enquête sur des musiciens ordinaires. Paris, La Découverte.

RUDENT Catherine (2008). "Le premier album de Mademoiselle K : Entre création individuelle et coopérations négociées ». Ethnologie française, 38(1) : 69-78.

SHAPIN Steven (1989). «The Invisible Technician ». American Scientist, 77(6) : 554-563.

WRIGHT David (2005). « Mediating Production and Consumption : Cultural Capital and "Cultural Workers" ». The British Journal of Sociology, 56(1) : 105-121.
LIzÉ Wenceslas (2016). "Artistic Work Intermediaries as Value Producers. Agents, Managers, Tourneurs and the Acquisition of Symbolic Capital in Popular Music." Poetics, 59: 35-49.

MaguiRe Jennifer \& MatThews Julian (2012). "Are We All Cultural Intermediaries Now? An Introduction to Cultural Intermediaries in Context." European Journal of Cultural Studies, 15(5): 551-562.

Mercier Denis (ed.) (2017). Le Livre des techniques du son. Tome 2, La technologie. Paris, Dunod.

NeGus Keith (2002). "The Work of Cultural Intermediaries and the Enduring Distance between Production and Consumption." Cultural Studies, 16(4): 501-515.

Perrenoud Marc (2007). Les Musicos. Enquête sur des musiciens ordinaires. Paris, La Découverte.

RUDENT Catherine (2008). "Le premier album de Mademoiselle K: Entre création individuelle et coopérations négociées." Ethnologie française, 38(1): 69-78.

SHAPIN Steven (1989). "The Invisible Technician." American Scientist, 77(6): 554-563.

WriGHT David (2005). "Mediating Production and Consumption: Cultura Capital and 'Cultural Workers'." The British Journal of Sociology, 56(1): 105-121. 